\title{
O gênero Billbergia Thunb. (Bromeliaceae) no Estado do Rio de Janeiro, Brasil ${ }^{1}$
}

\author{
Joana Viana de Barros² e Andrea Ferreira da Costa ${ }^{2,3}$
}

Recebido em 14/05/2007. Aceito em 25/04/2008

\begin{abstract}
RESUMO - (O gênero Billbergia Thunb. (Bromeliaceae) no Estado do Rio de Janeiro, Brasil). O gênero Billbergia Thunb. é atualmente constituído por 64 espécies distribuídos em dois centros de diversidade: a Mata Atlântica e a Floresta Amazônica. No Estado do Rio de Janeiro, o gênero é representado por 14 espécies ocorrentes em ecossistemas florestais e nas restingas: B. amoena (Lodd.) Lindl., B. brasiliensis L.B. Sm., B. distachia (Vell.) Mez, B. euphemiae E. Morren, B. horrida Regel, B. iridifolia (Nees \& Mart.) Lindl., B. lymanii E. Pereira \& Leme, B. macracantha E. Pereira, B. pyramidalis (Sims) Lindl., B. sanderiana E.Morren, B. tweediana Baker, B. vittata Brongn. ex C.Morel e B. zebrina (Herb.) Lindl. O trabalho consta de descrições, ilustrações e comentários taxonômicos e fitogeográficos das espécies.
\end{abstract}

Palavras-chave: Bromeliaceae, Rio de Janeiro, Mata Atlântica, Restinga

\begin{abstract}
The genus Billbergia Thunb. (Bromeliaceae) in Rio de Janeiro State, Brazil). The genus Billbergia Thunb. comprises 64 species occurring in two centers of diversity: Atlantic Forest and Amazon Forest. In Rio de Janeiro State, the genus is represented by 14 species found in Atlantic forest and restinga: B. amoena (Lodd.) Lindl., B. brasiliensis L.B. Sm., B. distachia (Vell.) Mez, B. euphemiae E. Morren, B. horrida Regel, B. iridifolia (Nees \& Mart.) Lindl., B. lymanii E. Pereira \& Leme, B. macracantha E. Pereira, B. pyramidalis (Sims) Lindl., B. sanderiana E. Morren, B. tweediana Baker, B. vittata Brongn. ex C.Morel and B. zebrina (Herb.) Lindl. Here we present descriptions, figures and notes on taxonomy and geographic distribution of the species.
\end{abstract}

Key words: Bromeliaceae, Rio de Janeiro, Atlantic Forest, Restinga

\section{Introdução}

O gênero Billbergia Thunb. compreende 64 espécies (Luther 2006) distribuídas desde a América Central até o sul da América Meridional (Smith \& Downs 1979). Os dois subgêneros, Billbergia e Helicodea Lem., apresentam um padrão disjunto de distribuição, sendo a Mata Atlântica o centro de diversidade para o primeiro e a Floresta Amazônica, o centro de diversidade para o segundo (Smith \& Downs 1979). Os dois grupos apresentam distinções morfológicas bem definidas como a densidade de indumento no escapo e na raque, a posição da inflorescência, a postura transversal das pétalas (Smith \& Downs 1979), o comprimento das anteras e a inserção do filete nestas.

No check list da família para o Estado do Rio de Janeiro, Fontoura et al. (1991) listaram 17 espécies e 14 táxons infraespecíficos de Billbergia. Três destes nomes foram posteriormente sinonimizados (Fontoura 1994) e dois materiais, que representavam a ocorrência
B. amoena var. minor (Antoine \& Beer ex Beer) L.B.Sm. foram reidentificados como B. amoena (Lodd.) Lindl. (Martinelli 4.539 RB e Araújo 7.467 GUA).

O trabalho teve como objetivos ampliar o conhecimento da morfologia e distribuição geográfica das espécies de Billbergia ocorrentes no Estado do Rio de Janeiro e subsidiar uma futura revisão taxonômica do gênero, além de contribuir para o conhecimento da Flora do Estado.

\section{Material e métodos}

O estudo taxonômico foi realizado a partir de levantamento bibliográfico, exame de coleções de herbário, de coleções vivas e excursões ao campo.

O levantamento nos herbários foi realizado prioritariamente nas coleções do Estado do Rio de Janeiro (R, RB, HB, GUA e RUSU). Foram examinados tipos e fotos dos tipos enviados pelos herbários $\mathrm{HB}, \mathrm{GH}, \mathrm{B}, \mathrm{K} \mathrm{e}$ LG. O material coletado foi depositado no herbário R

\footnotetext{
1 Parte da Dissertação de Mestrado da primeira Autora, Programa de Pós-graduação em Ciências Biológicas (Botânica), UFRJ

2 Universidade Federal do Rio de Janeiro, Museu Nacional, Departamento de Botânica, Quinta da Boa Vista, São Cristóvão, $20940-040$ Rio de Janeiro, RJ, Brasil

3 Autor para correspondência: afcosta@acd.ufrj.br
} 
(para as siglas, ver Holmgren \& Holmgren 1998).

As descrições do gênero e das espécies foram baseadas em materiais procedentes do Estado do Rio de Janeiro. A terminologia adotada para as descrições seguiu Radford (1986) e Weberling (1989).

A distribuição geográfica das espécies foi baseada em Smith \& Downs (1979), Moura et al. (2007) e Versieux \& Wendt (2006) e complementada com as coleções dos herbários consultados.

As ilustrações foram baseadas em material vivo.

\section{Resultados e discussão}

Das 17 espécies e 10 táxons infra-específicos reconhecidos para o Estado do Rio de Janeiro (Fontoura et al. 1991; Fontoura 1994), foram sinonimizadas uma espécie (B. cylindrostachya Mez sob B. zebrina (Herb.) Lindl.) e uma variedade (B. euphemiae var. nudiflora $\mathrm{L}$. B. Sm. sob B. euphemiae E. Morren). A notoespécie B. $x$ claudioi Leme, que não havia sido considerada por Fontoura et al. (1991), foi sinonimizada sob $B$. macracantha E. Pereira. Duas espécies foram consideradas pouco conhecidas (B. lietzei E. Morren e B. seidelii L.B.Sm. \& Reitz) e uma espécie foi considerada de ocorrência duvidosa para o Estado (B. morelii Brongn.).

Não foi adotada a taxonomia infraespecífica uma vez que os caracteres utilizados para delimitar esses táxons não puderam ser suficientemente avaliados nas coleções de herbários e nas populações das espécies. Desta forma são aqui reconhecidas 14 espécies ocorrentes no Estado do Rio de Janeiro.

Os seguintes caracteres mostraram-se importantes para a sistemática do gênero: distribuição do indumento no eixo reprodutivo; tamanho relativo, forma e orientação da bráctea do escapo; orientação da raque e comprimento dos entrenós; forma e padrão de cores das sépalas; postura transversal e padrão de cores das pétalas; e forma, tamanho e superfície do ovário. Os principais táxons com circunscrições duvidosas são os que compõem o complexo B. amoena. O confronto de um maior número de espécimes e novos trabalhos de campo serão úteis na eleição de caracteres diagnósticos, principalmente para os táxons com limites conceituais imprecisos.

\section{Billbergia Thunb.}

Plantas epífitas, rupícolas ou terrestres. Roseta tubular a infundibuliforme, com folhas geralmente cartáceas ou mais raramente subcoriáceas ou coriáceas. Escapo longo, ereto, subereto ou pendente, glabro a glabrescente ou com indumento flocoso ou lanuginoso, também presente na raque, no ovário e nas sépalas; brácteas do escapo elípticas, oblongas, lineares, triangulares ou lanceoladas, com ápice geralmente agudo, obtuso, apiculado ou não, as medianas e as superiores róseas, vermelhas ou estramíneas, patentes a suberetas, em geral flácidas, raramente papiráceas. Inflorescência laxa ou densa, em espiga ou espiga dupla, raque geniculada ou não, 4-30 flores. Flores sésseis ou curtopediceladas, tubulares, evidentes, actinomorfas ou zigomorfas, eretas, suberetas, patentes ou reflexas. Brácteas florais de tamanho e forma variáveis, as superiores menores que as inferiores até ausentes, com a mesma forma das brácteas do escapo ou não. Sépalas em geral oblongas, apiculadas, raramente pungentes, concolores, bicolores ou tricolores, simétricas ou assimétricas. Pétalas lineares, espatuladas ou oblanceoladas, livres, concolores ou bicolores, com um par de apêndices na base e, em geral, um par de calosidades longitudinais que flanqueiam os estames, recurvadas ou revolutas. Estames levemente mais curtos que as pétalas ou do mesmo comprimento, sempre exsertos na antese, bisseriados, isodínamos ou didínamos, sendo a série antissépala livre e a série antipétala adnata às pétalas por até $5 \mathrm{~mm}$; anteras basifixas ou dorsifixas; ovário ínfero, cilíndrico ou turbinado, liso ou sulcado; estigma conduplicado espiralado; tubo epigíneo 1-5 mm compr.; óvulos anátropos ou ortótropos, apiculados ou não. Frutos bagas globosas, carnosas ou rígidas, cálice persistente, sulcos do ovário persistentes ou não; sementes truncadas.

Chave para a identificação das espécies de Billbergia ocorrentes no Estado do Rio de Janeiro

1. Pétalas revolutas; anteras basifixas; ovário turbinado

13. B. zebrina

1. Pétalas recurvadas a fortemente recurvadas; anteras dorsifixas; ovário subcilíndrico ou cilíndrico

2. Lâmina foliar com mais de $70 \mathrm{~cm}$ compr. Escapo com mais de $90 \mathrm{~cm}$ compr. Flores eretas

2. Lâmina foliar com menos de $65 \mathrm{~cm}$ compr. Escapo com menos de $50 \mathrm{~cm}$ compr. Flores suberetas, patentes ou reflexas

3. Escapo e raque flocosos

4. Escapo pendente 4. B. euphemiae

4. Escapo ereto ou subereto 
5. Inflorescência laxa na base e densa no ápice. Sépalas com menos da metade do comprimento das pétalas. Pétalas amarelas com $1 / 4$ apical azul.... 2. B. brasiliensis

5. Inflorescência densa. Sépalas com metade do comprimento das pétalas ou mais. Pétalas totalmente vermelho-arroxeadas, vermelho-arroxeadas com 1/9 apical azul ou amarelas com $1 / 3$ apical azul 9. B. pyramidalis

3. Escapo e raque glabros a glabrescentes

6. Lâmina foliar com ruga na base

6. Lâmina foliar sem ruga na base

7. Inflorescência pendente, raramente subereta

8. Lâmina foliar com até $2,8 \mathrm{~cm}$ larg. e acúleos menores que $1 \mathrm{~mm}$ compr. Inflorescência sempre em espiga

9. Inflorescências com 4-10 flores. Brácteas florais inferiores e superiores 1,5-2 mm compr., mais curtas que o ovário, triangulares a ovadas 3. B. distachia

9. Inflorescências com 13-17 flores. Brácteas florais inferiores e superiores 1,5-8 cm compr., triangulares a estreito-elípticas, semelhantes às do escapo, as inferiores cobrindo as flores e as superiores cobrindo as sépalas

5. B. horrida

âmina foliar 3-6,8 cm larg. e acúleos 1-8 mm compr. Inflorescência em espiga dupla, raramente em espiga.

10. Brácteas do escapo largo-elípticas. Inflorescência com mais de $20 \mathrm{~cm}$ compr.

10. B. sanderiana

10. Brácteas do escapo lanceoladas a estreito-elípticas. Inflorescência até $18 \mathrm{~cm}$ compr.

11. Sépalas com ápice mucronado 12. B. vittata 11. Sépalas não pungentes 8. B. macracantha

7. Inflorescência laxa

12. Ovário subcilíndrico e liso

12. Ovário cilíndrico e sulcado.

13. Pétalas vermelhas com ápice azul. Sépalas assimétricas, vermelhas 14. Billbergia sp.

13. Pétalas totalmente verdes ou verdes com $1 / 8$ a 1/4 apical azul. Sépalas simétricas, verdes 7. B. lymanii 1. B. amoena

1. Billbergia amoena (Lodd.) Lindl., Bot. Reg. 13: sub pl. 1068. 1827.

Planta florida 35-55 cm alt., epífita, terrestre ou rupícola, roseta infundibuliforme. Folhas 10-18, suberetas a arqueadas, cartáceas; bainha 10-13x 4,1-8,2 cm; lâmina 12-45×2-5,7 cm, linear-lanceolada a lanceolada, verde ou vinácea, face abaxial com faixas transversais alvo-lepidotas ou não, ápice agudo ou obtuso arredondado, margem com acúleos 0,5-2 mm, escapo ereto a subereto, $20-36 \mathrm{~cm}, 1,5-8 \mathrm{~mm}$ diâm., verde a róseo, glabro a glabrescente, entrenós superiores 1,4-3,5 cm, brácteas do escapo 6-12×1,5-2,7 cm, elípticas a largo-elípticas, flácidas, róseas ou vermelhas, com colorido persistente, patentes, base envolvendo parcialmente o escapo, as superiores não cobrindo a inflorescência, ápice agudo ou obtuso arredondado, apiculado ou não. Inflorescência em espiga ou espiga dupla, laxa, 5-23 flores, 8-20×7-15 cm, verde, rósea ou vermelha, raque não geniculada, glabra a glabrescente, paracládios uni a triflorados, entrenós inferiores 0,7-3 cm, entrenós superiores 1-13 mm; brácteas primárias 5,2-10×1,5-3,5 $\mathrm{cm}$, cobrindo os paracládios. Brácteas florais inferiores e superiores minutas até ca $5 \mathrm{~mm}$, oblongas a deltóides, verdes, vermelhas ou róseas, ápice apiculado ou caudado, geralmente com apículo azul. Flores suberetas, 5,5-6,5 cm, sésseis, actinomorfas ou zigomorfas. Sépalas 1,9-3×0,5-0,7 cm, simétricas e raramente assimétricas, oblongas a oblongo-lanceolada, verdes com 1/6 a 1/5 apical azul, glabrescentes, ápice agudo ou obtuso arredondado, raramente oblíquo, apiculado ou não. Pétalas 4,2-5,3×0,65 cm, lineares a espatuladas, totalmente verdes ou verdes com $1 / 8$ a $1 / 4$ apical azul, recurvadas, ápice obtuso arredondado; apêndices 1,5-2 mm, semi-cupuliformes irregularmente fimbriados, calosidades ausentes ou atingindo 1,7 cm. Estames isodínamos, exsertos por ca. de 1,5 cm; filetes antipétalos adnatos às pétalas por ca. $2 \mathrm{~mm}$; anteras 5,0-5,5 mm, dorsifixas. Ovário 1,5-2,3 cm, 4-5 mm diâm., cilíndrico, sulcado a fortemente sulcado, verde; tubo epigíneo 3-5 mm; placentação mediano superior, 0,6-1 cm; óvulos ortótropos, apiculados ou não; estigma verde ou azul. Frutos bagas carnosas, $1,8 \mathrm{~cm}, 0,8-1 \mathrm{~cm}$ 
de diâmetro, sulcos persistentes.

Material selecionado: BRASIL. Rio de Janeiro: Angra dos Reis, Ilha Grande, Reserva Biológica da Praia do Sul, 16/V/1984, fl., Araújo 6283 (GUA). Araruama, Ponta das Andorinhas,14/II/1994, fl., Oliveira 827 (GUA). Armação de Búzios, VI/1981, fl., Leme 215 b (R); id., 31/VIII/2002, fl., Quinet 677 (RB); id., restinga de Manguinhos, 12/XI/1999, fl., Fernandes et al. 272 (RB). Arraial do Cabo, 16/I/2001, fr., Fernandes et al. 582 (RB). Cabo Frio, Morro do Gavião, 13/X/1968, fl., Sucre 3923 (RB); id., 22/II/1989, fl., Araújo 8740 (GUA). Campos, Ibitioca, Fazenda Pedra Negra, 10/X/1993, fl., Braga et al. 699 (GUA). Casimiro de Abreu, Barra de São João, 23/V/1964, fl., Carauta 211 (GUA, RB); id., Barra de São João, 14/VIII/1986, fl., Costa et al. 6 (RB). Itaguaí, 17/VII/1990, fl., Carauta 6081 (GUA). Macaé, estrada para Lagoa Comprida, 24/VII/1982, fl., Araújo 5186 (GUA); id., Pico do Frade, 16/IX/1982, fl., Martinelli \& Farney 8729 (RB); id., Pico do Frade, 18/II/1994, fl., Leme et al. 2296 (R); id., próximo do Parque Nacional da Restinga de Jurubatiba, 19/IX/2004, fl., Barros et al. 42 (R). Mangaratiba, alto da Praia Brava, s/d, fl., Leme 659 (R); id., Reserva Ecológica de Rio das Pedras, 26/V/1998, fl., Giordano et al. 2146 (RB). Maricá, Restinga da Barra, 9/V/1984, fl., Araújo 6252 (GUA); id., APA, leste do Morro do Mololo, 23/V/1986, fr., Araújo et al. 7467 (GUA). Niterói, Itacoatiara, III/1980, fl., Moutinho 89 (HB). Nova Iguaçu, 17/XI/1995, fl., Silva Neto 579 (RB). Nova Friburgo, Macaé de Cima, 25/X/1986, fl., Martinelli \& Leitman 11825 (RB). Parati, Sertão do Taquari, 5/VII/1989, bot., Farney et al. 2.325 (RB); id., Sertãozinho, km 158 da Rio-Santos, s/d, fl., Leme 2922 (R). Petrópolis, 7/XI/1967, fl., Braga 17 (RB); id., Vale das Videiras, 13/X/1974, fl., Martinelli 512 (RB); id., Vale das Videiras, 26/IX/1980, fl., Martinelli 7399 (RB). Rio de Janeiro, restinga de Jacarepaguá, 15/X/1958, fl., Pereira 4406 et al. (RB); id., restinga de Grumari, 31/VII/1968, fl., Sucre et al. 3379 (RB); id., Campo Grande, 30/V/1978, fl., Martinelli 4539 (RB); id., Parque Nacional da Tijuca, Serra dos Pretos Forros, 3/IX/1977, fl., Martinelli et al. 3117 (RB); id., Parque Ecológico da Prainha, 29/VI/2003, fl., Forzza et al. 2405 (RB); id., restinga de Marambaia, 4/VI/2004, fl., Barros et al. 28 (R). Santa Maria Madalena, Parque Estadual do Desengano, 18/IX/1986, bf., Martinelli et al. 11729 (RB). São Gonçalo, IX/1996, fl., Seidel 1052 (RB). São Pedro da Aldeia, Morro de Sapiatiba, 9/IX/1987, bf., Martinelli et al. 12198 (RB). Saquarema, restinga de Jaconé, 30/V/1978, fl., Martinelli 4539 (HB); id., restinga de Itaúna, 8/V/1985, fl., Farney et al. 710 (RB); id., Fazenda Ipitanga, 8/V/1985, fl., Araújo 6837 (GUA); id., restinga de Jacarepiá, 18/V/2005, fl., Barros et al.
72 (R). Teresópolis, Parque Nacional da Serra dos Órgãos, 10/V/1981, bf., Ribeiro 147 (GUA).

Distribuição geográfica: a espécie distribui-se nos Estados de Goiás, Bahia, Minas Gerais, Espírito Santo, Rio de Janeiro, São Paulo, Paraná e Santa Catarina, na Floresta Pluvial Atlântica, restinga, campos de altitude (Smith \& Downs 1979; Fontoura et al. 1991; Moura et al. 2007) e campos rupestres (Versieux \& Wendt 2006). No Rio de Janeiro é bem representada em quase todas as restingas, nas florestas montanas e nos campos de altitude da região serrana de Macaé.

A inflorescência com flores laxas, as brácteas do escapo e primárias elípticas a largo-elípticas, a raque e o escapo glabrescentes e expostos, as sépalas longas e o ovário cilíndrico e sulcado são características da espécie. No entanto, trata-se de uma espécie polimórfica, especialmente na forma da roseta, na morfologia foliar e da inflorescência, e na coloração das sépalas e pétalas, o que é refletido no grande número de binômios associados à espécie (16 sinônimos e sete variedades). Por este motivo, optou-se neste trabalho, por adotar a taxonomia em nível específico.

2. Billbergia brasiliensis L.B. Sm., Arq. Bot. Estado São Paulo: 105.1943.

Planta terrestre, epífita ou rupícola, roseta infundibuliforme a subtubular. Folhas 8-10, eretas na metade inferior e arqueadas na metade superior; bainha 19-20×7,2 cm; lâmina $57 \times 6 \mathrm{~cm}$, linear a lanceolada, ápice atenuado e apiculado, verde, face abaxial com faixas transversais alvo-lepidotas, margem com acúleos 0,5-1,5 mm, escapo ereto a subereto, ca $35-41 \mathrm{~cm}$, ca. $5 \mathrm{~mm}$ diâm., com indumento alvo flocoso, entrenós superiores 2,2-3,2 cm, brácteas do escapo $8-9 \times 1,2 \mathrm{~cm}$, triangulares a estreito-elípticas, róseas a estramíneas na antese, base não envolvendo o escapo, patentes, deixando o escapo evidente, as superiores cobrindo 1/8 da inflorescência, ápice agudo. Inflorescência em espiga, 28-30 flores laxamente dispostas na base e congestas no ápice, ca. $18 \times 4 \mathrm{~cm}$, raque não geniculada, alvo flocosa, entrenós inferiores ca. $6 \mathrm{~mm}$, entrenós superiores 2-4 $\mathrm{mm}$. Brácteas florais inferiores $7-8 \times 1,2-1,3 \mathrm{~cm}$, semelhantes às do escapo, as superiores ausentes. Flores suberetas, ca. $6 \mathrm{~cm}$, sésseis. Sépalas 1-1,7×0,6 cm, assimétricas, oblongas, róseas, alvo flocosas, carnosas, ápice obtuso retuso, oblíquo. Pétalas ca. $5 \mathrm{~cm}$, lineares, rosa-avermelhadas com 1/4 apical azul, fortemente recurvadas, ápice agudo; apêndices 2,5-3 mm. Anteras basifixas. Ovário ca. $1,5 \mathrm{~cm}$, ca. $6 \mathrm{~mm}$ diâm., cilíndrico, fortemente sulcado, rósea, alvo flocoso; estigma azul. Frutos não observados.

Material examinado: BRASIL. Rio de Janeiro: Mangaratiba, Reserva Ecológica de Rio das Pedras, 
19/VIII/1994, fl., Costa et al. 476 (RB). Parati, Paratimirim, 14/VII/1987, fl., Fontoura et al. 157 (RB); idem, 23/VII/1988, fl., Martinelli 12981 (RB); idem, APA Cairuçú, Trindade, Praia de Fora, 8/VIII/1994, fl., Marquete 1971 (RB).

Distribuição geográfica: na descrição original, feita a partir de espécime em cultivo, a procedência é indicada de maneira incerta para o Estado de Santa Catarina. Como não há registro de material em herbário para essa região, a procedência do local do tipo permanece sob suspeita. Reitz (1983) afirma a insuficiência de dados que confirme a ocorrência no Estado de Santa Catarina. A espécie é conhecida apenas para a região sul do Estado do Rio de Janeiro, entre Mangaratiba e Parati. Fontoura et al. (1991) já indicaram sua ocorrência para Paratimirim.

A espécie é afim a $B$. pyramidalis pela presença de faixas transversais alvo-lepidotas na face abaxial das lâminas, pela inflorescência simples e pelas flores superiores sem brácteas florais. Desta difere, no entanto, pelas brácteas superiores do escapo não cobrindo a inflorescência, pela inflorescência longa, com flores laxamente dispostas na base e congestas no ápice e pelo tamanho relativo da sépala: $1 / 3$ a $1 / 4$ do comprimento das pétalas.

3. Billbergia distachia (Vell.) Mez, Mart. Fl. bras. 3(3):417. 1892.

Fig. 1-8

Planta florida 40-60 cm alt., epífita ou rupícola, roseta tubular. Folhas 5-10, suberetas, as externas menores que as internas, cartáceas; bainha $17 \times 4-5,5 \mathrm{~cm}$; lâmina 17-41×1,8-3 cm, linear a lanceolada, verde, argênteo lepidoto na face abaxial, ápice acuminado, margem inteira ou com acúleos 0,2-1 $\mathrm{mm}$, escapo pendente, 34-47 cm, 1,5-2,5 mm diâm., verde, glabro, entrenós superiores $2-3 \mathrm{~cm}$ compr. brácteas do escapo 9-13×0,7-1,2 cm, estreito-elípticas, flácidas, róseas, com colorido persistente, base envolvendo completamente o escapo, imbricadas, margem involuta, as superiores não cobrindo a inflorescência, ápice agudo. Inflorescência em espiga, laxa, 4-10 flores, 7-13×5-13 cm, raque geniculada, glabra a glabrescente, alva ou rósea, entrenós inferiores 0,6-1,8 cm, entrenós superiores 5-7 mm. Brácteas florais inferiores e superiores 1,5-2,0 mm, mais curtas que o ovário, triangulares a ovadas, glabrescentes a puberulentas, ápice acuminado, as inferiores distintas das brácteas do escapo. Flores patentes, 5,9-6,5 cm, curto-pediceladas, pedicelo 1-2 mm, zigomorfas. Sépalas 1,8-2,2×0,5-1,1 cm, simétricas ou assimétricas, oblongo-obovadas a oblongo-lanceoladas, totalmente verdes ou verdes com pequena mácula apical azul, glabrescentes, ápice agudo, obtuso retuso ou arredondado, oblíquo ou não. Pétalas 4,6-5,2×0,6-0,7 cm, lineares a levemente espatuladas, totalmente verdes ou verdes com pequena mácula apical azul, recurvadas, ápice arredondado; apêndices 2,0-2,1 mm, semicupuliformes levemente fimbriados; calosidades até $1,9 \mathrm{~cm}$. Estames isodínamos a didínamos, exsertos por ca. 1,4 cm; filetes série antisépala ca. $4,9 \mathrm{~cm}$, série antipétala ca. $4,3 \mathrm{~cm}$, estas adnatas às pétalas por ca. $3 \mathrm{~mm}$; anteras ca. $5 \mathrm{~mm}$, dorsifixas. Ovário 1,3-1,4 cm, 4-6 mm diâm., subcilíndrico, fortemente sulcado, glabrescente; tubo epigíneo $2-8 \mathrm{~mm}$; placentação mediano-inferior ou mediano-superior. Frutos não observados.

Material selecionado: BRASIL. Rio de Janeiro: Itatiaia, 6/X/1945, fl., Altamiro \& Walter 19 (RB); id., Hotel Donati, 21/V/1962, fl., Castellanos 24020 (GUA); id., 13/VII/1902, fl., Dusén 724 (R); id., 18/VI/1930, fl., Brade 10078 (R). Resende, Serrinha, s.d., fl., Leme 722 (R).

Distribuição geográfica: a espécie distribui-se pelos Estados de Minas Gerais, Rio de Janeiro, São Paulo, Paraná e Santa Catarina, ocorrendo mais freqüentemente na Floresta Pluvial Atlântica montana e alto-montana (Smith \& Downs 1979; Fontoura et al. 1991), e raramente em campos rupestres e matas de galeria no cerrado do Estado de Minas Gerais (Versieux \& Wendt 2006). No Rio de Janeiro a sua distribuição é restrita a Serra da Mantiqueira, na região do Parque Nacional do Itatiaia.

A espécie é característica por apresentar roseta com poucas folhas, com indumento argênteo na face abaxial, escapo e raque com diâmetros reduzidos, brácteas do escapo imbricadas, com a base envolvendo completamente o escapo, inflorescência em espiga pauciflora e laxa, brácteas florais inferiores distintas das do escapo, flores sésseis a subsésseis, patentes, zigomorfas e ovário fortemente sulcado. Billbergia distachia var. concolor Reitz foi descrita com base na ausência de mácula apical azul nas sépalas e nas pétalas. De acordo com Smith \& Downs (1979) e com o levantamento nos herbários, sua ocorrência se sobrepõe com a distribuição da variedade típica no Rio de Janeiro já que também ocorre no Parque Nacional de Itatiaia.

4. Billbergia euphemiae E. Morren, Belgique Hort. 22: 11, pl. 1, 2. 1872.

=Billbergia euphemiae var. nudiflora L.B. Sm., Smithson. Misc. Collect. 126:20. 1955. Tipo: Espírito Santo, Itapemirim, 7/VII/1939, Foster 159 (holótipo, $\mathrm{GH}$; isótipo, R!) syn. nov.

Fig. 9-15

Planta florida $20-45 \mathrm{~cm}$ alt., rupícola, terrestre ou epífita, roseta tubular. Folhas 6-8 suberetas a arqueadas divaricatas, cartáceas a subcoriáceas, as externas mais curtas; bainha $14 \times 3,2-5 \mathrm{~cm}$; lâmina $33-64 \times 2,4-4 \mathrm{~cm}$, 


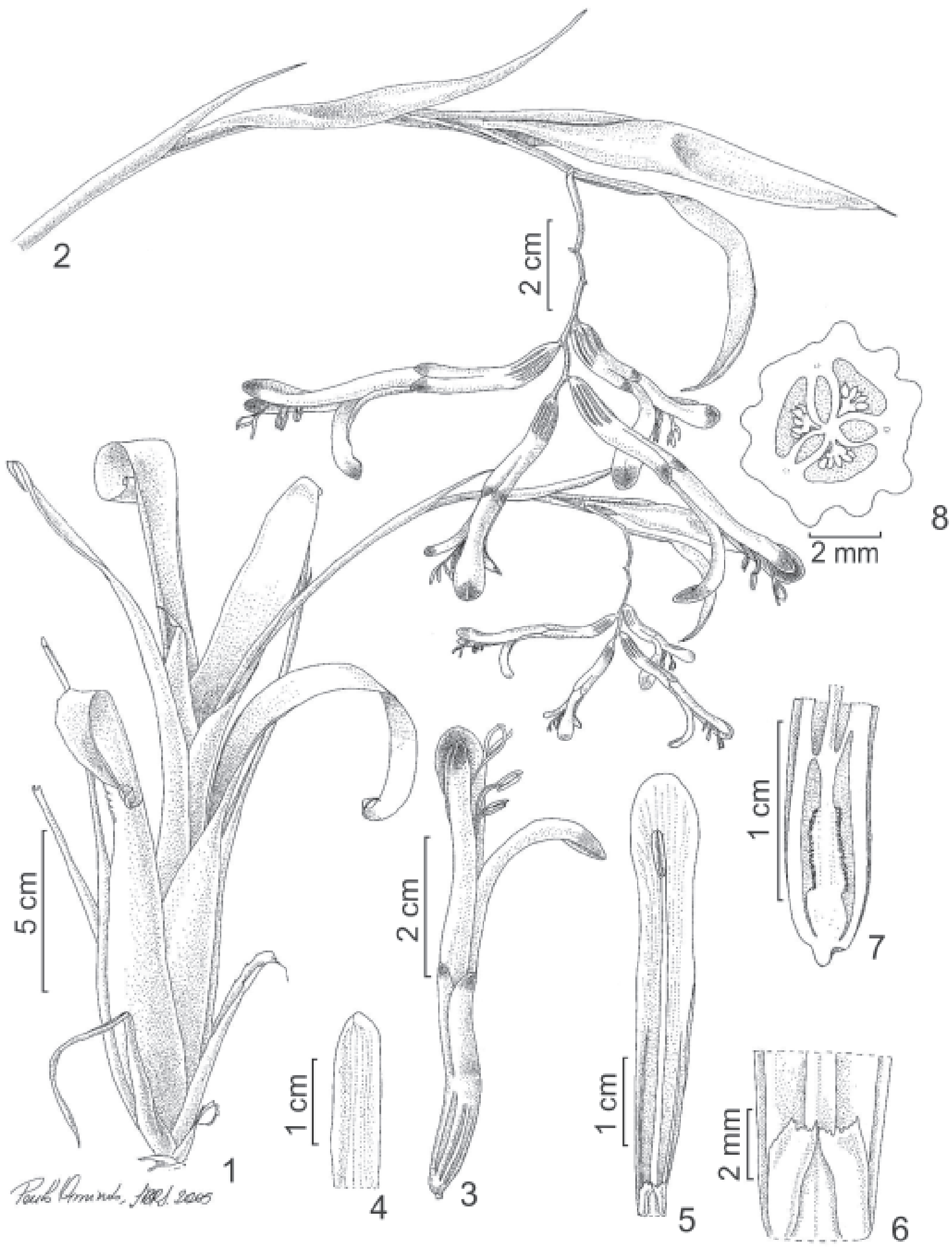

Figuras 1-8. Billbergia distachia (Vell.) Mez. 1. Hábito. 2. Inflorescência. 3. Flor. 4. Sépala. 5. Pétala e estame. 6. Detalhe apêndices petalíneos. 7. Ovário em secção longitudinal. 8. Ovário em secção transversal (Leme 722). 


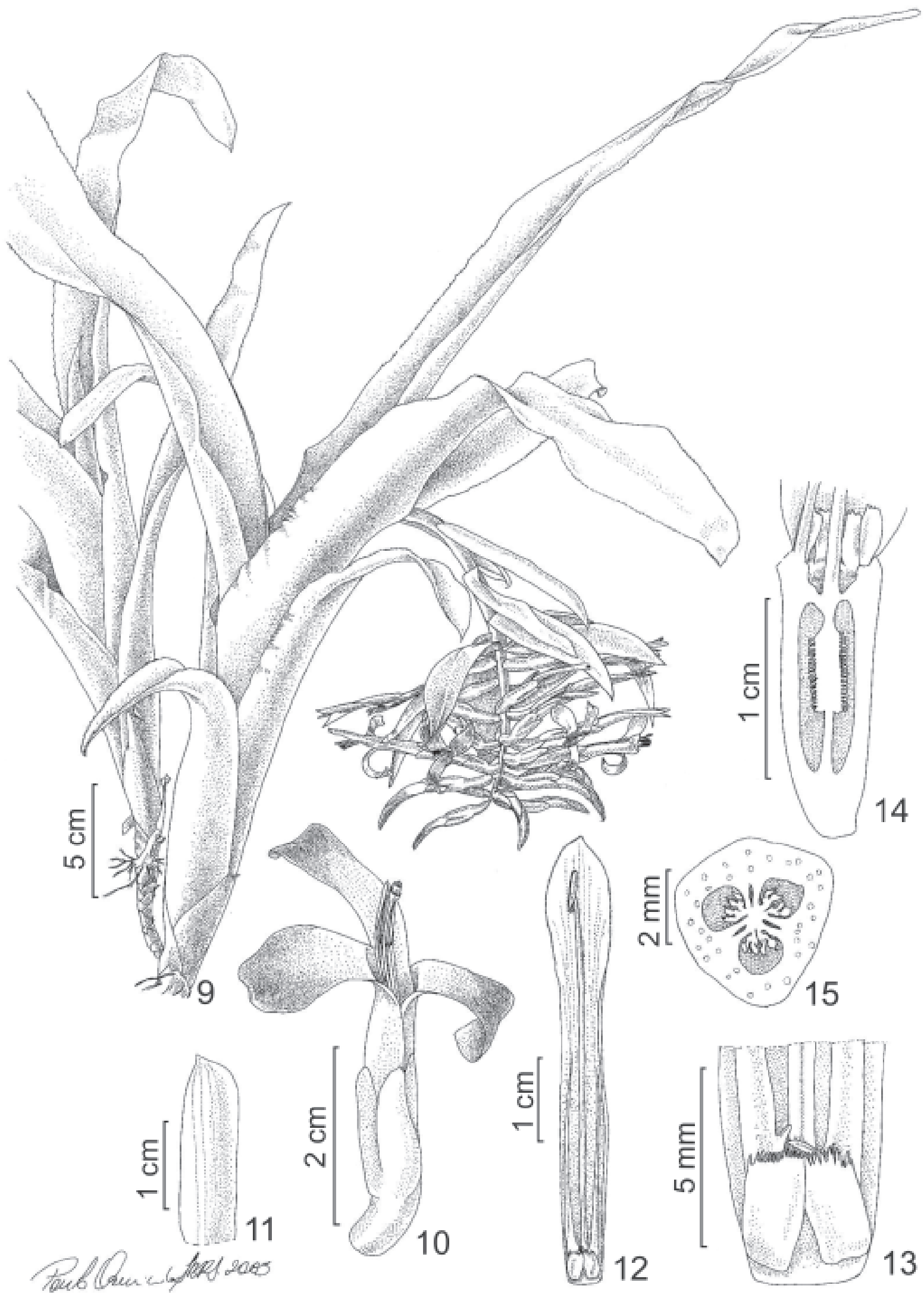

Figuras 9-15. Billbergia euphemiae E. Morren. 9. Hábito. 10. Flor. 11. Sépala. 12. Pétala e estame. 13. Detalhe apêndices petalíneos. 14. Ovário em secção longitudinal. 15. Ovário em secção transversal (Marquete 2030). 
linear-lanceolada a oblanceolada, verde, face abaxial com faixas transversais alvo-lepidotas ou não, ápice acuminado, margem inteira ou com acúleos 0,5-1 mm, escapo pendente, 22-35 cm, 1-4 mm diâm., róseo, alvoflocoso; entrenós superiores 6-7 $\mathrm{mm}$ compr. brácteas do escapo 4,5-8,3×1,5-2 cm, elípticas a largo-elípticas, flácidas a papiráceas, róseas na pré-antese e, em geral, estramíneas na antese, base envolvendo parcialmente o escapo, suberetas a patentes, as superiores cobrindo a base da inflorescência, ápice agudo. Inflorescência em espiga, laxa a densa, 6-20 flores, 5-15×8,2-11 cm, rósea, raque geniculada ou não, alvo-flocosa, entrenós inferiores 3-7 mm, entrenós superiores 1-5 mm. Brácteas florais inferiores 2,5-6,9×0,5-2,3 cm, semelhantes às do escapo, superiores minutas, estreito-ovadas a elípticas, róseas, ápice acuminado. Flores patentes a reflexas, $5-6 \mathrm{~cm}$, sésseis a curto-pediceladas, pedicelo ca. $0,5 \mathrm{~mm}$, zigomorfas. Sépalas $1,5-2 \times 0,65-0,8 \mathrm{~cm}$, simétricas ou assimétricas, oblongas a oblongo-obovadas, róseas, alvoflocosas, ápice obtuso arredondado, apiculado. Pétalas 4,3-5,2×0,65-0,9 cm, espatuladas, verdes ou amarelas com $1 / 3$ a $1 / 4$ apical azul, recurvadas, ápice agudo ou obtuso arredondado; apêndices ca. $3 \mathrm{~mm}$, semicupuliformes regularmente fimbriados; calosidades 1,5-2,2 cm. Estames isodínamos, exsertos por ca. $1,3 \mathrm{~cm}$; filetes antipétalos adnatos às pétalas por $5-7 \mathrm{~mm}$ alt.; anteras ca. $5 \mathrm{~mm}$, dorsifixas. Ovário $0,6-1,3 \mathrm{~cm}$, ca. 7 mm diâm., subcilíndrico, liso a levemente sulcado, branco ou róseo, alvo flocoso; tubo epigíneo ca. $1 \mathrm{~mm}$; placentação mediano-superior; óvulos apiculados; estigma verde. Frutos não observados.

Material selecionado: BRASIL. Rio de Janeiro: Armação de Búzios, mata do Olho de Boi, 1/VIII/2003, fl., Araújo 10836 (GUA). Campos, Mata de Bom Jesus, 15/V/1989, fl., Araújo 8787 (GUA). Carapebus, Praia da Capivara, 5/V/1997, fl., Moura 50 (R). Macaé, Loteamento Lagomar, 29/IX/1998, fl., Araújo 10672 (GUA). Petrópolis, Vale das Videiras 10/X/1979, fl., Martinelli 6137 (RB). Santa Maria Madalena, 19/X/1995, fl., Marquete et al. 2412 (RB); id., 18/X/1994, fl., Marquete 2030 (RB).

Distribuição geográfica: a espécie distribui-se pelos Estados Bahia, Espírito Santo, Minas Gerais e Rio de Janeiro na Floresta Pluvial Atlântica montana e altomontana (Smith \& Downs 1979; Fontoura et al. 1991) e nas restingas (Moura et al. 2007). Versieux \& Wendt (2006) indicam uma ocorrência em campos rupestres de Minas Gerais. No Rio de Janeiro a espécie ocorre em populações pouco numerosas nas matas de restinga do norte fluminense e nas matas de encosta da Serra dos Órgãos e da Serra do Desengano.

A espécie é característica por apresentar indumento alvo flocoso no escapo, na raque, nas sépalas e no ovário, pelas brácteas do escapo congestas na base da inflorescência e geralmente estramíneas na antese, pelas flores zigomorfas, patentes a reflexas, pelo ovário liso a pouco sulcado e pelo padrão de cores das flores. Smith (1955) descreveu B. euphemiae var. nudiflora com base na presença da inflorescência subdensa, raque quase reta e brácteas florais reduzidas. O exame do material tipo desta variedade confirmou a similaridade morfológica deste material com os demais identificados como representantes da variedade típica.

5. Billbergia horrida Regel, Ind. Sem. Hort. Petrop. for 1856:17. 1857.

Fig. 16-25

Planta florida 40-50 cm alt., epífita ou rupícola, roseta tubular. Folhas ca. 10, eretas a suberetas, coriáceas; bainha 12-30×4,6-6,0 cm; lâmina 22-40× $2-5,5 \mathrm{~cm}$, linear-lanceolada a oblanceolada, base marcada com uma ruga, verde, glabra, ápice agudo a obtuso arredondado, margem com acúleos 2-3,5 mm, nigrescentes. escapo ereto, $36-47 \mathrm{~cm}, 2,7-5 \mathrm{~mm}$ diâm., verde, glabro, entrenós superiores $0,9-2,7 \mathrm{~cm}$, brácteas do escapo 6,8-11,5×1,2-1,6 cm, estreito-elípticas, papiráceas, verdes na pré-antese e pardas na antese, base envolvendo parcialmente o escapo, suberetas a patentes, deixando o escapo evidente, margem involuta, as superiores não cobrindo a inflorescência, ápice agudo com ou sem tufo de pêlos. Inflorescência em espiga, densa, 20-35 flores, 10,5-11×8,5-9 cm, raque não geniculada, glabra a glabrescente, verde, entrenós inferiores 1-1,5 mm, entrenós superiores 0,5-1 mm. Brácteas florais inferiores e superiores 1-9 mm, triangulares a ovadas, verdes a pardas, ápice agudo com ou sem tufos de pêlos. Flores suberetas, 4,7-6,5 cm, sésseis, actinomorfas. Sépalas 1,4-1,9×0,35-0,6 cm, assimétricas, oblongo-obovadas, totalmente verdes ou verdes com pequena mácula apical azul, glabras, ápice subtruncado, oblíquo, com ou sem tufo de pêlos. Pétalas 4,2-4,7×0,3-0,6 cm, fortemente espatuladas, brancas, totalmente verdes ou verdes com 1/10 apical azul, fortemente recurvadas, ápice obtuso arredondado; apêndices 1,5-2,2 mm, semi-cupuliformes levemente fimbriados; calosidades ausentes ou até $1,5 \mathrm{~cm}$. Estames isodínamos, exsertos ca. $2 \mathrm{~cm}$; filetes antipétalos adnatos às pétalas por ca. $3 \mathrm{~mm}$; anteras ca. $4,5 \mathrm{~mm}$, dorsifixas. Ovário 1-1,8 cm, cilíndrico, liso, verde, glabro; tubo epigíneo ca. 1,2 mm; placentação mediano-superior, 0,5-0,7 mm; estigma verde. Frutos não observados.

Material selecionado: BRASIL. Rio de Janeiro: Nova Friburgo, Parque Estadual Furnas do Catete, 26/X/1986, fl., Fontoura et al. 17 (RB; RUSU). Petrópolis, Serra da Estrela, s.d., fl., Kuhlman \& Brade 13106 (RB); id., Pedro do Rio, 2/III/1968, fl., Braga 


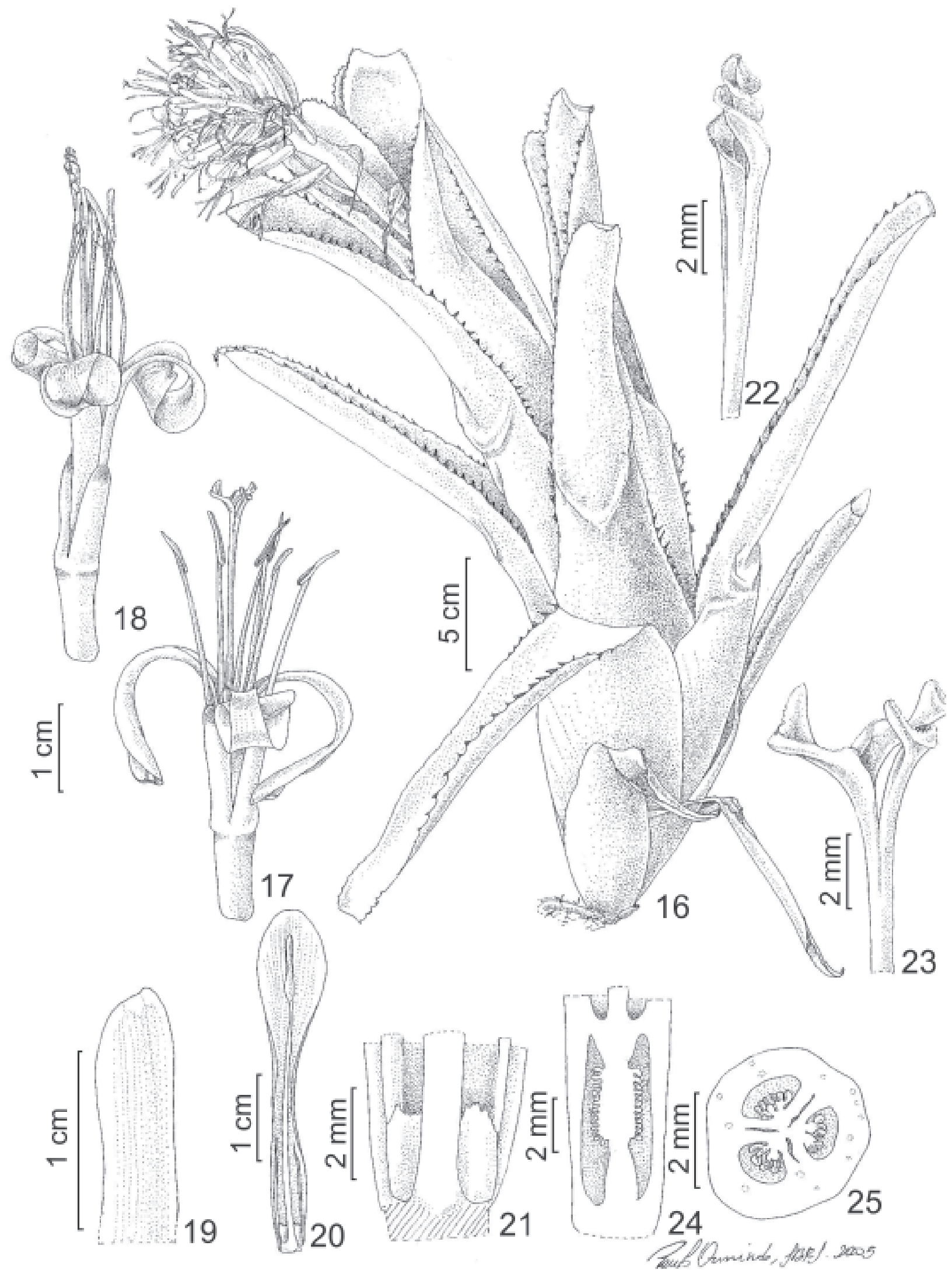

Figuras 16-25. Billbergia horrida Regel. 16. Hábito. 17. Flor 18. Flor em plena antese. 19. Sépala. 20. Pétala e estame. 21. Detalhe apêndices petalíneos. 22. Estigma espiralado. 23. Estigma desespiralado. 24. Ovário em secção longitudinal. 25. Ovário em secção transversal (Barros 50). 
1548 (RB). Rio de Janeiro, Parque Nacional da Tijuca, Açude da Solidão, 25/IX/65, fl., Santos 6013 (R); id., estrada da Vista Chinesa, XI/1999, fl., Vianna et al. 2502 (GUA); id., 28/IX/2004, fl., Barros 50 (R). Santa Maria Madalena, Serra da Furquilha, 20/XII/1991, fl., Wendt et al. 227 (RB); id., Santo Antônio do Imbé, 18/X/1994, fl., Marquete et al. 2.018 (RB).

Distribuição geográfica: a espécie ocorre nos Estados de Minas Gerais, Espírito Santo, Rio de Janeiro (Smith \& Downs 1979; Fontoura et al. 1991), e na Bahia (Versieux \& Wendt 2006) na Floresta Pluvial Attântica até 1.050 metros de altitude. No Estado do Rio de Janeiro é freqüente nas florestas da capital, mas também ocorre na Serra dos Órgãos e na Serra do Desengano.

A espécie é distinta das demais por apresentar roseta tubular robusta, folhas com ruga na base da lâmina, escapo glabro e crasso, brácteas do escapo papiráceas, pardas e involutas, raque glabra, inflorescência densa, flores actinomorfas alvas ou esverdeadas, máculas azuis reduzidas ou ausentes nas sépalas e pétalas, e pétalas recurvadas.

6. Billbergia iridifolia (Nees \& Mart.) Lindl., Bot. Reg. 13: pl. 1068. 1827.

Fig. 26-32

Planta florida $40-55 \mathrm{~cm}$ alt., epífita ou rupícola, roseta tubular. Folhas 4-5, eretas na metade inferior e arqueadas na metade superior, cartáceas; bainha 10,5-15×2,5-2,7 cm; lâmina 40-55×1,9-2,8 cm, lanceolada, canaliculada, verde, com tricomas na face abaxial, ápice agudo a acuminado, margem com acúleos 0,4-0,5 mm, escapo pendente, 20-26 cm, 1-3 mm diâm., róseo, glabro a glabrescente, entrenós superiores 1,3-3,7 cm, brácteas do escapo 5,9-8,1×1,2-1,9 cm, triangulares a estreito-elípticas, flácidas, róseas, em geral com colorido persistente, a base envolvendo parcialmente o escapo, suberetas a patentes, deixando o escapo evidente, as superiores não cobrindo a inflorescência, ápice agudo. Inflorescência em espiga, laxa, 13-17, 10-19×10-16 cm, raque geniculada em toda a extensão ou somente nos entrenós superiores, glabra a glabrescente, rósea, entrenós inferiores 1,2-3 cm, entrenós superiores $0,5-1 \mathrm{~cm}$. Brácteas florais inferiores e superiores 1,5-8 $\times 0,4-1,2 \mathrm{~cm}$, semelhantes às do escapo, as inferiores cobrindo as flores e as superiores cobrindo as sépalas, róseas, ápice acuminado. Flores patentes $3,5-5,3 \mathrm{~cm}$, sésseis a curto-pediceladas, pedicelo ca. $2 \mathrm{~mm}$, zigomorfas. Sépalas $1,8-2,2 \times 0,5-0,6 \mathrm{~cm}$, simétricas ou assimétricas, oblongo-lanceoladas a lanceoladas, verdes ou amarelas com 1/5 apical azul, ou base rósea com porção mediana amarela e ápice azul, glabrescentes, ápice obtuso arredondado, apiculado ou não. Pétalas 4,2-4,3×0,6 cm, lineares a levemente espatuladas, amarelas com 1/5 apical azul, recurvadas, ápice obtuso arredondado; apêndices 2,5-3 mm, semicupuliformes irregularmente fimbriados a lacerados; calosidades até 1,6 mm. Estames isodínamos, exsertos por 1-1,2 cm; anteras ca. $4 \mathrm{~mm}$, dorsifixas. Ovário 0,8-1 cm, 4-6 mm diâm., subcilíndrico, fortemente sulcado, róseo, glabrescente; tubo epigíneo 0,5-2 $\mathrm{mm}$; placentação mediano-superior, ca. $2,5 \mathrm{~mm}$; estigma verde. Frutos não observados.

Material examinado: BRASIL. Rio de Janeiro: Arraial do Cabo, ilha de Cabo Frio, s/d, fl., Moura s.n. (R205740). Cabo Frio, fl., Brade 19765 (RB). Campos, VIII/1939, fl., Sampaio 8359 (R). Casimiro de Abreu, Barra de São João, 12/VIII/1962, fl., Pabst 7020 (HB). Niterói, 30/VIII/1961, fl., Brade 11057 (R); id., Itacoatiara, Alto Moirão, 23/VIII/1979, fl., Almeida 28 (GUA). Rio de Janeiro, Serra da Carioca, 17/VIII/1941, fl., Pereira 14 (RB); id., vertente sul do Pão de Açúcar, 17/VIII/1973, fl., Sucre \& Araújo 10093 (HB, RB). Saquarema, próximo à restinga de Massambaba, 12/IX/1986, fl., Farney et al. 1182 (RB).

Distribuição geográfica: a espécie distribui-se pelos Estados da Bahia, Minas Gerais, Espírito Santo, Rio de Janeiro (Smith \& Downs 1979; Fontoura et al. 1991; Moura et al. 2007) na Floresta Pluvial Atlântica, nas matas de restinga, e campos rupestres, até $810 \mathrm{~m}$ de altitude (Versieux \& Wendt 2006). No Estado do Rio de Janeiro ocorre principalmente em matas de restinga e florestas montanas.

A espécie se distingue das demais pela roseta tubular com folhas canaliculadas, raque longa e geniculada, inflorescência laxa, brácteas florais inferiores e superiores semelhantes às do escapo (sendo que as inferiores igualam as flores e as superiores igualam as sépalas), flores sésseis a curto-pediceladas, zigomorfas, padrão de cores das flores e forma e comprimento do ovário.

7. Billbergia lymanii E. Pereira \& Leme, Bradea 4: 72,76. 1984.

Planta florida 30-36 cm alt., rupícola, roseta infundibuliforme. Folhas 9-14, suberetas, cartáceas; bainha ca. $8,5 \times 2,6 \mathrm{~cm}$; lâmina ca. $32 \times 1,6-2,2 \mathrm{~cm}$, triangular, verde ou vinácea, face abaxial com faixas transversais alvo-lepidotas ou não, ápice agudo ou obtuso-arredondado, margem com acúleos 0,5-2 $\mathrm{mm}$. escapo ereto, ca. $22 \mathrm{~cm}, 1-1,5 \mathrm{~mm}$ diâm., verde a róseo, glabro a glabrescente, entrenós superiores $1,4-3,5 \mathrm{~cm}$, brácteas do escapo 5-5,5×0,6-0,9 cm, linear-lanceoladas a elípticas, flácidas, róseas ou vermelhas, com colorido persistente, patentes, base envolvendo parcialmente o escapo, as superiores não cobrindo a inflorescência, ápice agudo, apiculado ou não. Inflorescência em espiga, laxa, 6-7 flores, 7-11×4-5,5 cm, raque não geniculada, 


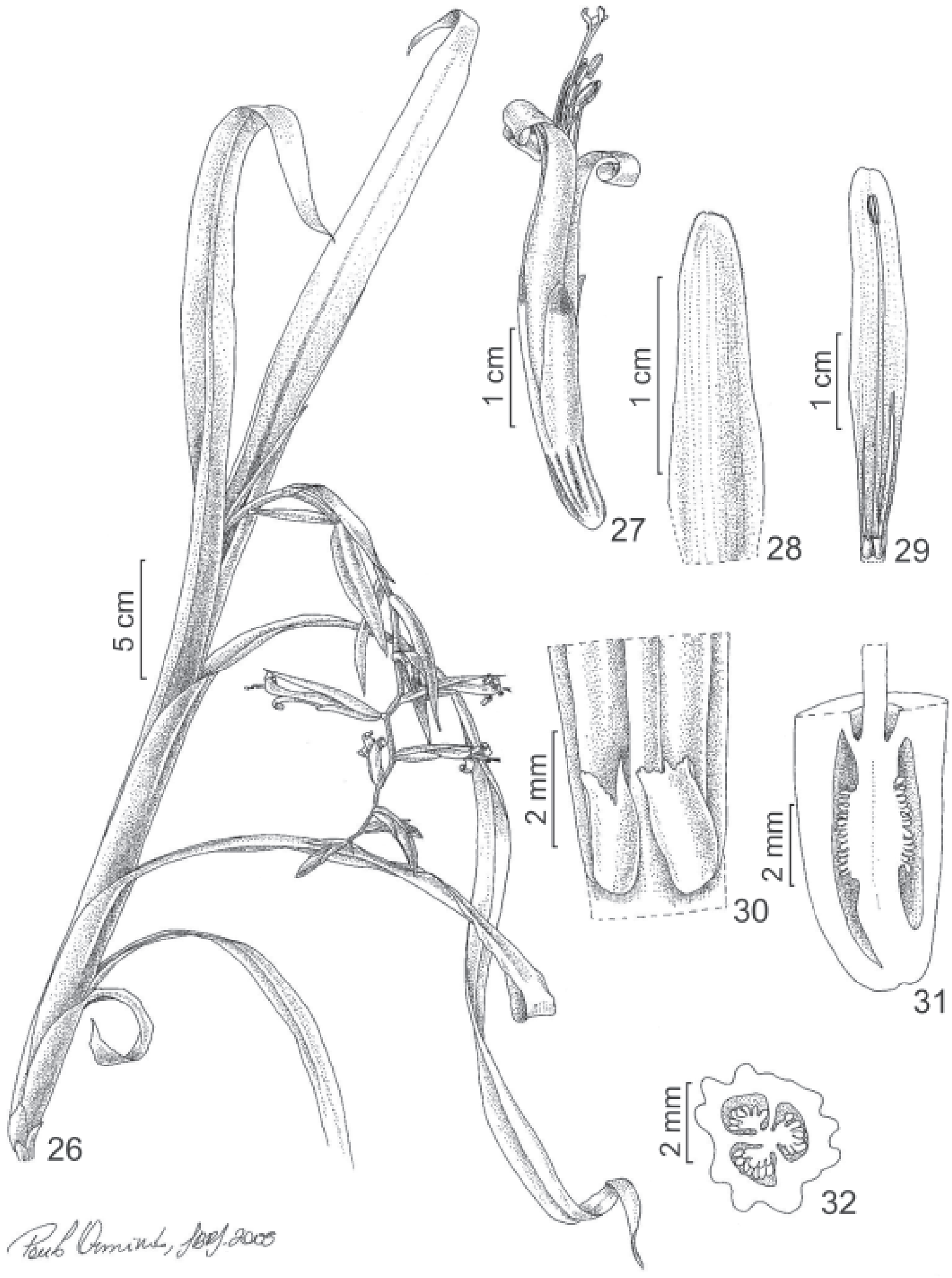

Figuras 26-32. Billbergia iridifolia (Nees \& Mart.) Lindl. 26. Hábito. 27. Flor. 28. Sépala. 29. Pétala e estame. 30. Detalhe apêndices petalíneos. 31. Ovário em secção longitudinal. 32. Ovário em secção transversal (Moura s.n. R205740). 
glabra a glabrescente, entrenós inferiores $0,5-0,7 \mathrm{~cm}$, entrenós superiores ca. $2 \mathrm{~mm}$. Brácteas florais inferiores ca. $5,5 \times 0,8 \mathrm{~cm}$, cobrindo as flores, semelhantes às do escapo; as superiores minutas até ca. $5 \mathrm{~mm}$, oblongas a deltóides, verdes, vermelhas ou róseas, ápice apiculado ou caudado, geralmente com apículo azul. Flores suberetas, 5,5-6,5 cm, as inferiores curto-pediceladas, pedicelo $1-5 \mathrm{~mm}$ e as superiores sésseis, actinomorfas ou zigomorfas. Sépalas 1,7-2,1×0,4 cm, assimétricas, oblongas, vermelhas, glabrescentes, ápice truncado, apiculado, oblíquo. Pétalas 4,2-5,3×0,65 cm, oblanceoladas, vermelhas com ápice azul. Estames isodínamos, exsertos por ca. $1,5 \mathrm{~cm}$; filetes antipétalos adnatos às pétalas por 5-10 mm. Ovário 1,7-1,9 cm, cilíndrico, liso, vermelho; estigma azul. Frutos não observados.

Material examinado: BRASIL. Rio de Janeiro: Petrópolis, Morro do Cuca, VII/1982, fl, Martinelli s.n. (HB, RB 231601).

Distribuição geográfica: conhecida somente pelo espécime-tipo de B. lymanii var. angustifolia, portanto, de ocorrência endêmica para o Morro do Cuca. Embora Fontoura et al. (1991) tenham considerado B. lymanii var. lymanii, ocorrente para no município de Saquarema, o mal estado do material depositado no herbário (Farney 134, RB) comprometeu a confirmação de sua identidade.

Billbergia lymanii apresenta duas variedades distintas pela largura da lâmina foliar. Ambas apresentam ocorrência para o Rio de Janeiro. A variedade típica foi descrita para o Estado do Espírito Santo e seus autores a relacionaram com $B$. vittata pelo padrão de cores e pela postura das pétalas, embora desta diferindo pela presença de indumento no escapo e na raque, pelo ápice das sépalas não setoso e pelas flores pediceladas. A partir do exame do material tipo, a espécie parece apresentar uma afinidade maior $\operatorname{com} B$. amoena pelo porte reduzido, pelos acúleos minutos, pela consistência foliar e pela arquitetura da inflorescência. Billbergia lymanii var. angustifolia E. Pereira \& Leme foi descrita com base em um único material (Martinelli s.n. (HB, holótipo; RB231601, isótipo) e não foi recoletada durante o trabalho.

8. Billbergia macracantha E. Pereira, Sellowia 26: 79. 1975.

=Billbergia $x$ claudioi Leme, Bradea 4: 314. 1987. Tipo:

Rio de Janeiro, Resende, Serrinha, VIII/1986, Leme

\& Menescal (HB! 72852, holótipo; RB! 261402 isótipo) syn. nov.

Planta florida $40-50 \mathrm{~cm}$ alt., epífita, roseta tubular. Folhas 7-8, eretas, coriáceas; bainha 17-20×6 cm; lâmina 24-43×3-3,4 cm, lanceolada, verde, glabra, ápice agudo, margem com acúleos 1-6 mm, nigrescentes. escapo ereto ou subereto, $32-43 \mathrm{~cm}, 1-2 \mathrm{~mm}$ diâm., róseo a roxo, glabro a glabrescente, entrenós superiores $2-3 \mathrm{~cm}$, brácteas do escapo $10-12 \times 1,2-1,4 \mathrm{~cm}$, oblongas, lanceoladas ou estreito-elípticas, flácidas, vermelhas, róseas ou alaranjadas, com colorido persistente, a base envolvendo parcialmente o escapo, suberetas a patentes, deixando o escapo evidente, as superiores não cobrindo a inflorescência, ápice agudo ou obtuso arredondado, apiculado ou não. Inflorescência em espiga ou espiga dupla, laxa, 12-17 flores, 12,5-13,5×5-8,2 cm, raque não geniculada a fracamente geniculada, glabra a glabrescente, entrenós inferiores 1,5-2 cm, entrenós superiores $2-5 \mathrm{~mm}$, brácteas primárias $8 \times 0,8 \mathrm{~cm}$, geralmente cobrindo os paracládios. Brácteas florais inferiores ca. $3,5 \mathrm{~cm}$, semelhantes às do escapo, as superiores $0,2-1,2 \mathrm{~cm}$, deltóides. Flores suberetas a patentes, ca. $6 \mathrm{~cm}$, sésseis a curto-pediceladas. Sépalas 1,9-2,5×0,4-0,6 cm, simétricas, oblongas, róseas com 1/5 apical azul, glabrescentes, ápice obtuso-arredondado. Pétalas 4,9-5,2×0,6 cm, espatuladas, ápice obtusoarredondado. Estames isodínamos, exsertos por ca. $2,3 \mathrm{~cm}$; filetes antipétalos adnatos às pétalas por ca. $2 \mathrm{~cm}$; anteras 4-6,5 mm, dorsifixas a ca. $2 \mathrm{~mm}$ da base. Ovário 0,9-1,5 cm, 4-5 mm diâm., cilíndrico, sulcado, verde, glabrescente; tubo epigíneo ca. $3 \mathrm{~mm}$. Frutos não observados.

Material examinado: BRASIL. Rio de Janeiro: Nova Friburgo, 1/X/1973, fl., Seidel 670 (HB, holótipo).

Distribuição geográfica: a espécie é conhecida somente pelos espécimes-tipo e apresenta ocorrência para os municípios de Nova Friburgo e Rezende.

A espécie é afim a $B$. vittata pela roseta tubular, pelos acúleos evidentes e nigrescentes, pela inflorescência laxa em espiga simples ou dupla e ovário sulcado. No entanto, B. vittata é distinta pelo ápice das sépalas levemente recurvado, obcordado a emarginado com mucro rígido. Apesar de B. vittata apresentar ocorrência para Nova Friburgo (Pereira 10588 e Seidel 714) o exame do material tipo de $B$. macracantha confirmou a ocorrência do ápice das sépalas obtuso-arredondado.

Foi proposta a sinomização da notoespécie $B \cdot x$ claudioi no presente trabalho devido à similaridade morfológica em relação à $B$. macracantha. Faz-se necessário o exame da obra original e do tipo de $B$. vittata para melhor avaliação de sua circunscrição já que ambas as espécies relacionadas, B. macracantha e B. x claudioi, ocorrem dentro de seu domínio geográfico. Trabalhos de campo complementares são necessários para avaliar se o ápice das sépalas, característica utilizada para diagnosticar as espécies, está bem aplicado para este fim ou se reflete uma variação morfológica dentro de populações. 
9. Billbergia pyramidalis (Sims) Lindl., Bot. Reg. 13: sub pl. 1068. 1827.

Fig. 33-40

Planta florida 40-50 $\mathrm{cm}$ alt., terrestre ou rupícola, roseta infundibuliforme. Folhas $8-15$, arqueadas, cartáceas; bainha 10-18×4,5-7,2 cm; lâmina $25-40 \times$ 3,4-6 cm, lanceolada, verde, face abaxial com faixas transversais alvo lepidotas ou não, ápice agudo apiculado, margem com acúleos ca. 0,5 mm, escapo ereto, $26-47 \mathrm{~cm}, 2-5 \mathrm{~mm}$ diâm., branco, alvo flocoso, entrenós superiores $0,3-1 \mathrm{~cm}$, brácteas do escapo 5-9×1,1-2,2 cm, elípticas a largo-elípticas, flácidas, róseas, com colorido persistente, base envolvendo parcialmente o escapo, suberetas a patentes, deixando o escapo evidente, as superiores suberetas, cobrindo 1/3 a 1/2 da inflorescência, ápice agudo. Inflorescência em espiga, densa, 6-20 flores, 5-18×3,3-10 cm, raque não geniculada, alvo flocosa, branca, entrenós inferiores 0,8-5 mm, entrenós superiores 2-3 mm. Brácteas florais inferiores semelhantes às do escapo, ca. $0,8 \mathrm{~mm}$, as superiores minutas ou ausentes. Flores suberetas, 4-6,7 cm, sésseis a subsésseis, pedicelo $0,8-1 \mathrm{~mm}$, actinomorfas. Sépalas 1,5-2×0,6-1 cm, assimétricas, oblongas a obovadas, rosa, alvo flocosas, ápice obtuso arredondado, oblíquo. Pétalas 4,3-4,6×0,9 cm, espatuladas, totalmente vermelho-arroxeadas ou vermelho-arroxeadas com 1/9 apical azul, ou ainda amarelas com 1/3 apical azul, recurvadas, ápice obtusoarredondado; apêndices 2-2,7 mm, semi-cupuliformes, irregularmente fimbriados a lacerados; calosidades até $2 \mathrm{~cm}$, uni a trifurcadas. Estames isodínamos, exsertos por 1,4-1,7 cm; filetes antipétalos adnatos às pétalas ca. $3 \mathrm{~mm}$; anteras ca. $4,5 \mathrm{~mm}$, dorsifixas. Ovário 1,5-1,7 cm, ca. $5 \mathrm{~mm}$ diâm., subcilíndrico a cilíndrico, liso a levemente sulcado, branco, flocoso; tubo epigíneo 1-4 mm; placentação mediano-superior; óvulos anátropos; estigma azul ou verde. frutos bagas carnosas, ca. $2 \mathrm{~cm}$, ca. $1 \mathrm{~cm}$ diâm., cálice persistente, lisos, sementes truncadas.

Material selecionado: BRASIL. Rio de Janeiro: Angra dos Reis, Ilha Grande, vila Dois Rios, 16/XI/2001, fr., Gonçalves et al. 287 (HB). Armação de Búzios, 21/IV/1981, fl., Souza 400 (GUA); id., Praia de Manguinhos, 8/III/2001, bot., Fernandes et al. 583 (RB). Cabo Frio, Morro do Gavião, 13/X/1968, fl., Sucre 3911 (RB; parátipo); id., 14/X/1968, fl., Sucre 3957 (RB; parátipo); id., Fazenda Campos Novos, ilha de Jacaré, 27/III/1979, fl., Araújo 2277 (GUA); id., ilha da Boa Vista, 24/IV/1979, fl., Carauta 3097 (HB); id., 28/VII/1995, fl., Araújo et al. 10321 (GUA, RB). Cachoeiras de Macacú, 28/II/1968, fl., Carauta 576 (GUA). Casimiro de Abreu, entre Barra de São João e Rio das Ostras, 20/III/1979, fl., Martinelli 5689 (RB); id., Barra de São João, 29/XI/1981, fl., Martinelli 7801 (RB, parátipo). Duque de Caxias, Xerém, 19/I/1997, bf., Santana et al. 27 (HB). Engenheiro Paulo de Frontin, mata da fazenda S. Sebastião, 12/VI/1998, fl., s.d., Silva 72 (R). Macaé, Pico do Frade, 17-21/VI/1937, fl., Brade 15836 (RB); id., distrito do Sana, 11/IX/2004, fl., Barros 38 (R); id., ARIE Itapebussus, 5/XII/2004, fl., Barros 64 (R). Magé, 14/I/1984, fl., Guedes et al. 617 (RB). Maricá, Restinga de Maricá, mata, 1/IV/1997, fl., Moura 40 (R). Miguel Pereira, 14/XII/2001, fl., Sylvestre et al. 1590 (RB). Niterói, Pico Alto Morão, 25/XI/1981, fl., Andreta 205 (RB, RUSU); id., Itaipú, Morro das Andorinhas, 15/I/1982, fl., Araujo et al. 4774 (GUA). Nova Friburgo, Reserva Ecológica de Macaé de Cima, caminho da serra dos Pirineus, 2/XII/1991, fl., Costa et al. 390 (RB); id., Macaé de Cima, II/1992, fl., Wendt et al. 237 (RB). Nova Iguaçu, Reserva Biológica do Tinguá, s/d, est., Héron 327 (R); id., Floresta Protetora, Serra da Bandeira, 17/X/1977, fl., Araujo et al. 1867 (GUA). Petrópolis, Serra da Estrela, 17/VII/1967, fl., Pereira 10608 (HB); id., mata do Judeu, 7/XII/1968, fl., Sucre et al. 4234 (RB); id., Araras, Pedra da Maria Comprida, 16/XI/1975, fl., Martinelli 785 (RB); id., Serra da Estrela, 9/III/1978, fl., Martinelli 4031 (RB). Rio das Ostras, I/1978, est., Leme 118-C (RB, holótipo); id., Reserva Biológica União, 1/IV/2000, fl., Costa et al. 715 (R). Rio de Janeiro, Morro Dois Irmãos, 18/III/1944, fl., Segadas Vianna 350 (R); id., Floresta da Tijuca, Pico do Papagaio, 31/I/1960, fl., Carauta 133 (R); id., Vista Chinesa, 30/XII/1960, fl., Strang 228 (GUA); id., Alto da Boa Vista, 23/XII/1995, fl., Oliveira 1.119 (GUA); id., trilha para Gruta Geonoma, 11/XII/2002, Oliveira 2150 (GUA); id., restinga de Itapeba, 17/V/1964, fl., Santos 5560 (R); id., Grajaú, IV/1968, fl., Emygdio 2634 (R); id., Recreio dos Bandeirantes, 28/IV/1968, fl., Segadas Vianna 4634 (R); id., Taquara da Tijuca, 17/V/1972, fl., Sucre et al. 9125 (RB); id., Pedra da Gávea, 24/II/1978, fl., Carauta et al. 2851 (GUA, RB); id., Jacarepaguá, 4/VIII/1990, fl., Farney et al. 2.408 (RB); id., Horto Florestal, 23/II/1994, fl., Marquete et al. 1464 (RB); id., Parque Municipal do Prainha, 9/X/2003, fl., Calvente et al. 55 (RB, RUSU). São Pedro d'Aldeia, morro de Sapiatiba, 9/IX/1987, fl., Martinelli et al. 12199 (RB). Saquarema, restinga de Ipitangas, 13/VI/1987, fl., Farney et al. 1401 (RB); id., Reserva Ecológica Estadual Jacarepiá, 25/VI/1990, fl., Fontoura et al. 175 (RB). Teresópolis, Parque Nacional da Serra dos Órgãos, 21/X/1977, fl., Martinelli et al. 3315 (RB).

Distribuição geográfica: a espécie distribui-se pelos Estados da Bahia, de Minas Gerais, do Espírito Santo, Rio de Janeiro e de São Paulo nas matas de restinga e na Floresta Pluvial Atlântica montana (Moura et al. 2007). 


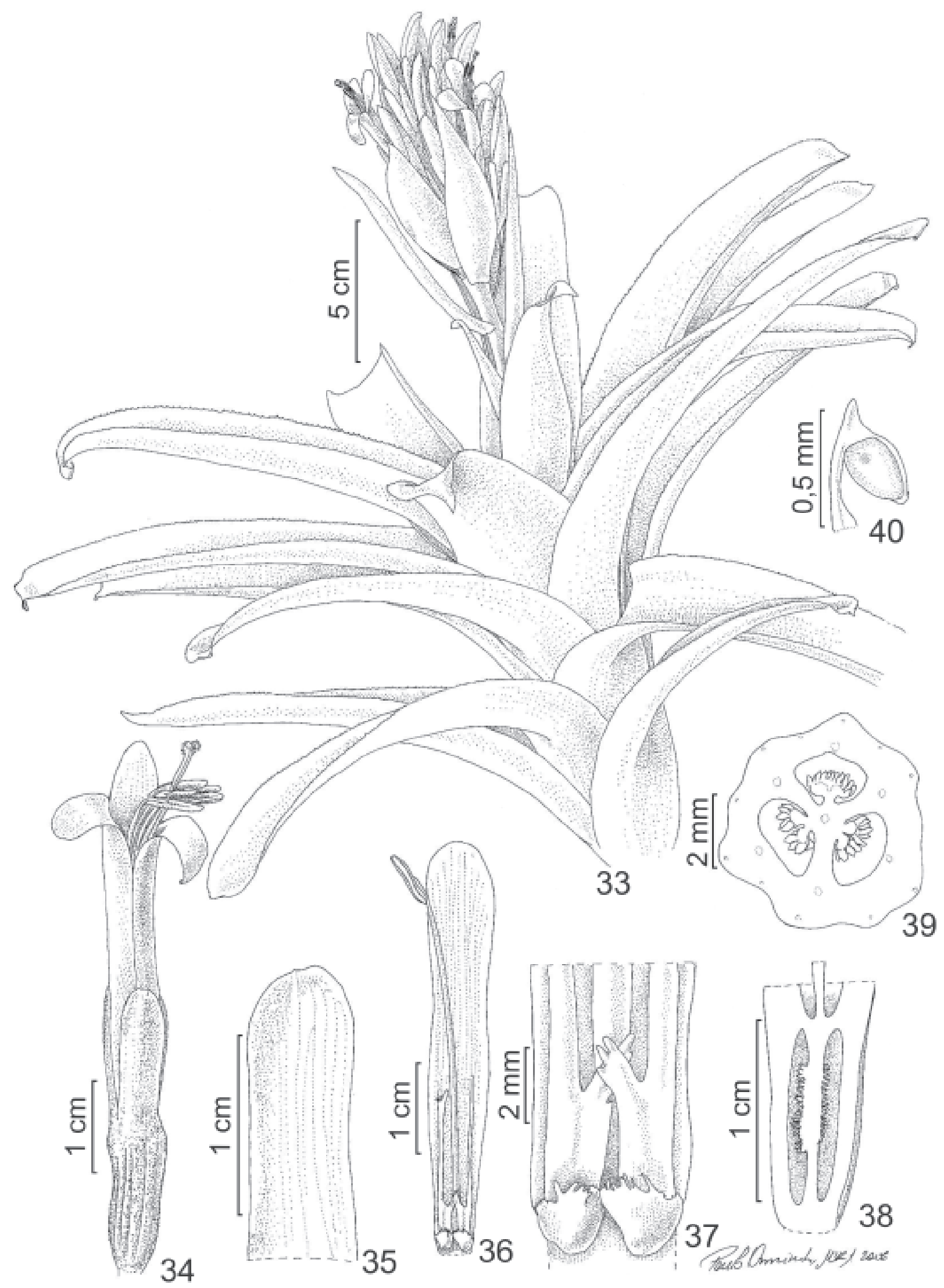

Figuras 33-40. Billbergia pyramidalis (Sims) Lindl. 33. Hábito. 34. Flor. 35. Sépala. 36. Pétala e estame. 37. Detalhe apêndices petalíneos e calosidades. 38. Ovário em secção longitudinal. 39. Ovário em secção transversal. 40. Óvulo (Heron 327). 
A ocorrência para o Estado do Pará, Venezuela, Cuba e ilhas do Caribe, indicadas por Smith \& Downs (1979) deve ser confirmada através do exame dos materiais citados. No Estado do Rio de Janeiro a espécie é amplamente distribuída, ocorrendo tanto nas florestas montanas quanto nas matas de restinga, geralmente em extensas populações nos sub-bosques.

Billbergia pyramidalis apresenta quatro variedades distintas pela coloração das pétalas. Devido à ausência desta informação na maioria das etiquetas de herbário a identificação precisa do material é dificultada, assim como a determinação da distribuição geográfica de cada uma delas.

10. Billbergia sanderiana E. Morren, Belgique Hort. 34: 17-19, pls. 1, 2.1884.

Planta florida 40-50 cm alt., epífita, roseta infundibuliforme. Folhas 10-18, suberetas a arqueadas, cartáceas; bainha 16-17×5-8,7 cm; lâmina 16-21× 3,6-6 cm, lanceolada a levemente obovada com estreitamento em direção à base, verde, glabra, ápice agudo ou obtuso arredondado, retuso ou não, margem com acúleos 2,5-7 mm, nigrescentes. escapo pendente, 25-32 cm, 2-6 mm diâm., verde ou róseo, glabro a glabrescente, entrenós superiores $2,5-3 \mathrm{~cm}$, brácteas do escapo 6-7×2-4 cm, largo-elípticas, suborbiculares ou obovadas, margem inteira ou serrada, flácidas, róseas, com colorido persistente ou as superiores pardas na antese, base envolvendo parcialmente o escapo, suberetas, ápice agudo ou obtuso arredondado, apiculado ou não. Inflorescência em espiga dupla, laxa na base e congesta em direção ao ápice, 17-20 flores, 20-25x $12 \mathrm{~cm}$, raque não geniculada, glabra a glabrescente, verde ou rósea, paracládios uniflorados a triflorados, entrenós inferiores 1,8-2,5 cm, entrenós superiores ca. $5 \mathrm{~mm}$, brácteas primárias $5-7 \times 3-3,5 \mathrm{~cm}$ semelhantes às brácteas do escapo, porém mais curtas e mais largas, cobrindo os paracládios inferiores. Brácteas florais 0,3-1,2×0,3-0,6 cm, oblongo-lanceoladas a elípticas, róseas ou azuis, ápice acuminado a arredondado, com ou sem apículo. Flores inferiores patentes a reflexas e superiores suberetas a patentes, ca. $6,5 \mathrm{~cm}$, sésseis, actinomorfas ou zigomorfas. Sépalas $1,8-2,7 \times 0,6-0,7 \mathrm{~cm}$, simétricas ou assimétricas, oblongo-lanceoladas, com base rósea, porção mediana branca e 1/10 apical azul, ápice agudo ou obtuso arredondado, apiculado, oblíquo ou não. Pétalas 3,7-4,2×3,5-4 cm, lineares a levemente espatuladas, verdes com 1/6 apical azul, recurvadas, ápice obtuso-arredondado; apêndices ca. $2 \mathrm{~mm}$, semicupuliformes, levemente fimbriados; calosidades até ca. $2 \mathrm{~cm}$. Estames isodínamos, exsertos por ca. 1,4 cm; anteras ca. $5 \mathrm{~mm}$, dorsifixas. Ovário 1,6-1,7 cm, cilíndrico, fortemente sulcado, verde, glabrescente; tubo epigíneo 2-4 mm compr.; placentação completa; estigma roxo. Frutos não observados.

Material selecionado: BRASIL. Rio de Janeiro: Nova Iguaçu, estrada de Lagoa das Lontras para Tinguá, 17/VI/1998, fl., Silva 82 (R). Nova Friburgo, Macaé de Cima, Sítio Sofronites, 1/XII/1992, fl., Wendt 238 (RB). Miguel Pereira, VI/98, est., Silva 21 (HB). Petrópolis, 23/VII/1968, fl., Braga 24 (RB). Teresópolis, Serra dos Órgãos, 1952, fl., Vidal II-2236 (R); id., Casacata do Imbuí, s/d, fl., Sampaio 2696 (R); id., s/d, fl., Leme 1870 (HB).

Distribuição geográfica: a espécie distribui-se pelos Estados de Minas Gerais, Rio de Janeiro, Espírito Santo (Fontoura et al. 1991) na Floresta Pluvial Atlântica. No Rio de Janeiro a sua ocorrência é registrada para a Serra do Mar entre os municípios de Nova Iguaçu e Nova Friburgo.

As folhas curtas e largas com acúleos nigrescentes, com estreitamento na base, as brácteas do escapo e as primárias largas suborbiculares, obovadas ou largoelípticas, o escapo pendente e a inflorescência longa, composta e laxa são características típicas da espécie. Uma boa ilustração da espécie é fornecida por Smith \& Downs (1979).

11. Billbergia tweediana Baker, Handb. Bromel.: 73. 1889.

Fig. 41-45

Planta florida 0,8-1,2 m alt., rupícola ou terrestre, roseta tubular. Folhas 4-6, eretas, coriáceas; bainha 20-25×10 cm; lâmina 70-93×6,4-10 cm, linear lanceolada, verde, ápice obtuso-arredondado, margem com acúleos 0,5 mm, escapo ereto, 90-98 cm, 3-5 mm diâm., verde, glabro, entrenós superiores $7-16 \mathrm{~cm}$; brácteas do escapo 16-21×2,2-3,2 cm, oblongo-lanceoladas a estreito-elípticas, paleáceas, estramíneas na antese, base envolvendo totalmente o escapo, imbricadas, deixando escapo parcialmente evidente, as superiores não cobrindo a inflorescência, ápice obtuso-arredondado, apiculado ou não. Inflorescência em espiga dupla, laxa, 7-12 flores, ca. $19 \times 20 \mathrm{~cm}$, raque não geniculada, glabra, verde, paracládios 3-6 flores, entrenós inferiores 3,5-9 cm, entrenós superiores $3,5-5 \mathrm{~cm}$, brácteas primárias 11-15×1-2,5 cm cobrindo os paracládios. Brácteas florais $2-5 \times 3 \mathrm{~mm}$, oblongo-ovadas a triangulares, verdes a estramíneas na antese, ápice apiculado. Flores eretas, ca. $6,5 \mathrm{~cm}$, sésseis, actinomorfas. Sépalas 1,4-1,5× 0,6-0,7 cm, assimétricas, oblongas, verdes ou amarelas, glabrescentes, ápice obtuso-arredondado a subtruncado, oblíquo, apiculado. Pétalas $4 \times 0,7 \mathrm{~cm}$, lineares a oblanceoladas, brancas, recurvadas, ápice obtuso arredondado; apêndices $0,8-1 \mathrm{~cm}$, adnatos às pétalas por ca. $4 \mathrm{~mm}$, espatulados com projeções lobadas; 

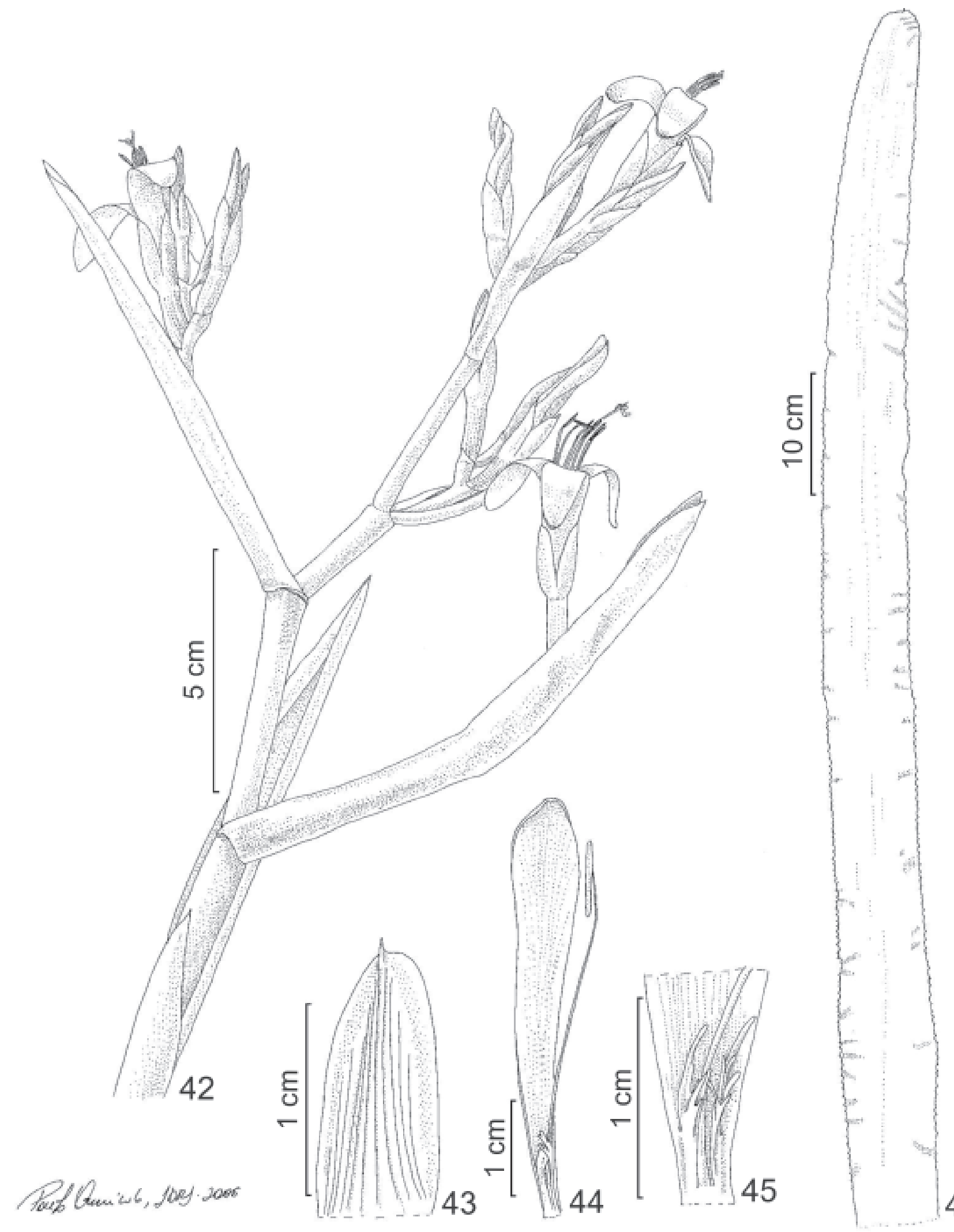

Figuras 41-45. Billbergia tweediana Baker. 41. Lâmina foliar. 42. Inflorescência. 43. Sépala. 44. Pétala e estame. 45. Detalhe apêndices petalíneos (Silva 803). 
calosidades ausentes. Estames isodínamos, exsertos por ca. $1,8 \mathrm{~cm}$; anteras $7-8 \mathrm{~mm}$, dorsifixas. Ovário 1,2-1,6 cm, ca. 4 mm diâm., cilíndrico, liso a levemente sulcado, verde, glabrescente; tubo epigíneo ca. $1 \mathrm{~mm}$; estigma verde. Frutos bagas carnosas, ca. $2,2 \mathrm{~cm}, 4 \mathrm{~mm}$ diâm., sulcos persistentes.

Material selecionado - BRASIL. Rio de Janeiro: Armação de Búzios, Praia das Focas, 20/VIII/1980, fl., Martinelli 7394 (HB); id., 15/VIII/1999, fl./fr., Farney 3927 (RB). Arraial do Cabo, terras das Salinas Perynas, 26/VIII/1987, fl., Araújo 8039 et al. (GUA); id., Ilha de Cabo Frio, III/1999, fl., Silva 803 (RB, R); id. Ilha de Cabo Frio, Casa dos Coronéis, enseada da Parede, 10/XI/2004, fl., Barros 59 (R). Cabo Frio, restinga do Peró, 17/IX/1968, fr., Sucre 3696 (RB); id., Morro do Farol da Laginha, 29/III/1986, fl., Araújo 7545 (GUA); id., Praia de Tucuns, próx. a Ponta do Marisco, 22/IX/1987, fr., Araújo 8166 (GUA);. Macaé, Ilha de Santana, 16/XI/1968, fr., Araújo 8654 et al. (GUA). Rio de Janeiro, Ilha de Paquetá, 23/IX/1984, fl., Augusto 386 (R); id., Tapuamas de Fora, 30/IX/1984, fl., Cardoso 387 (R). Rio das Ostras, restinga da Praia Virgem, 28/VIII/1999, fl., Damasceno 1128 (RB). Santa Maria Madalena, margem do Rio Grande, 29/IX/1979, fl., Moutinho \& Ventura 33 (HB). Saquarema, comoros da Lagoa Vermelha, 20/X/1988, fr., Araújo 8615 et al. (GUA).

Distribuição geográfica: a espécie distribui-se pelos Estados do Rio de Janeiro, Espírito Santo (Smith \& Downs 1979) e Minas Gerais (Fontoura et al. 1991; Moura et al. 2007; Versieux \& Wendt 2006), na Floresta Pluvial Atlântica até $650 \mathrm{~m}$ de altitude, restingas e costões rochosos próximos ao mar. No Rio de Janeiro a espécie é mais frequiente em matas de restinga e costões, onde forma densas populações, tendo uma única coleta para floresta montana.

O porte da planta, as folhas largas e coriáceas, as brácteas do escapo e as primárias estramíneas na antese floral, a inflorescência em espiga dupla tirsóide, as flores com pétalas brancas, os apêndices petalares bem desenvolvidos e o ovário estreito caracterizam a espécie.

Smith (1955) descreveu B. tweediana var. latisepala com base unicamente na relação do comprimento das sépalas com a sua largura. $\mathrm{O}$ material tipo da espécie B. decipiens, descrita por Pereira \& Reitz (1975) e posteriormente tratada como sinônimo de B. tweediana var. latisepala (Smith \& Downs 1979), foi examinado e foi constatado que o tratamento dado por Smith \& Downs (1979) foi coerente. A análise de materiais depositados em herbários evidenciou que a dimensão das sépalas, caráter que motivou Smith a descrição do novo táxon, é variável e não deve ser utilizada na sistemática do grupo. A falta de exame do material tipo da referida variedade não possibilitou a sua sinonimização neste artigo.

Segundo os critérios da IUCN foi classificada como apresentando "Dados Deficientes" no Workshop para revisão da Lista de espécies da flora brasileira ameaçada de extinção realizado pela Fundação Biodiversitas em 2005.

12. Billbergia vittata Brongn. ex C. Morel, Portef. Hortic. 2: 353, pl. 1848.

Fig. 46-54

Planta florida $40-50 \mathrm{~cm}$ alt., epífita, roseta tubular. Folhas 7-8, eretas, coriáceas; bainha 16,5-23x 7,5-8,2 cm; lâmina 18-22,5×3,5-6,8 cm, lanceolada, verde, glabra, ápice obtuso-arredondado a obtusotruncado, margem com acúleos 4-8 $\mathrm{mm}$, nigrescentes. escapo subereto a pendente, $40-44$ cm, 2-3 mm diâm., róseo a roxo, glabro a glabrescente, entrenós superiores 2-3 cm, brácteas do escapo 8,5-9,7×1,5-2,2 cm, oblongas, lanceoladas ou estreito-elípticas, flácidas, vermelhas, róseas ou alaranjadas, com colorido persistente, a base envolvendo parcialmente o escapo, suberetas a patentes, deixando o escapo evidente, as superiores não cobrindo a inflorescência, ápice agudo ou obtuso-arredondado, apiculado ou não. Inflorescência em espiga geralmente dupla, laxa, 12-24 flores, 11-20x $11-20 \mathrm{~cm}$, raque não geniculada a fracamente geniculada, glabra a glabrescente, rósea, vermelha ou alaranjada, paracládios uni a bifloros, entrenós inferiores $1,5-3 \mathrm{~cm}$, entrenós superiores $2-5 \mathrm{~mm}$, brácteas primárias $8-9 \times$ 2-2,5 cm, geralmente cobrindo os paracládios. Brácteas florais inferiores e superiores $0,2-1,2 \mathrm{~cm}$, triangulares a oblongo-lanceoladas, ou inferiores semelhantes às do escapo, róseas, ápice apiculado. Flores patentes, 6-6,5 $\mathrm{cm}$, sésseis a subsésseis, pedicelo $1 \mathrm{~mm}$. Sépalas 2,2-2,5×0,45-0,7 cm, simétricas, oblongo-lanceoladas, róseas com 1/5 apical azul, glabrescentes, ápice emarginado a obcordado, recurvado, mucronado, mucro ca. $1 \mathrm{~mm}$. Pétalas 4,9×0,46-0,6 cm, oblanceoladas ou espatuladas, róseas com 1/3 apical azul, fortemente recurvadas, ápice obtuso-arredondado; apêndices 1-3 mm, semi-cupuliformes fimbriados ou lacerados; calosidades ausentes ou até $1,5 \mathrm{~cm}$. Estames isodínamos, exsertos por ca. $2,3 \mathrm{~cm}$; filetes antipétalos adnatos às pétalas por ca. $2 \mathrm{~cm}$; anteras $6 \mathrm{~mm}$, dorsifixas a ca. $2 \mathrm{~mm}$ da base. Ovário 1,0-1,8 cm, 4-5 mm diâm., cilíndrico, liso a levemente sulcado, róseo, vermelho ou azul, glabrescente; tubo epigíneo 1,5-2,5 mm; placentação 3/4 inferiores, $6,5-7 \mathrm{~mm}$; óvulos ortótropos; estigma verde ou azul. Frutos bagas carnosas, ca. $1,5 \mathrm{~cm}, 0,9 \mathrm{~cm}$ diâm., globosos, sem constrição na base do tubo epigíneo, liso, sementes truncadas.

Material selecionado - BRASIL. Rio de Janeiro: Engenheiro Paulo de Frontin, 12/VI/1998 fl., Rezende 


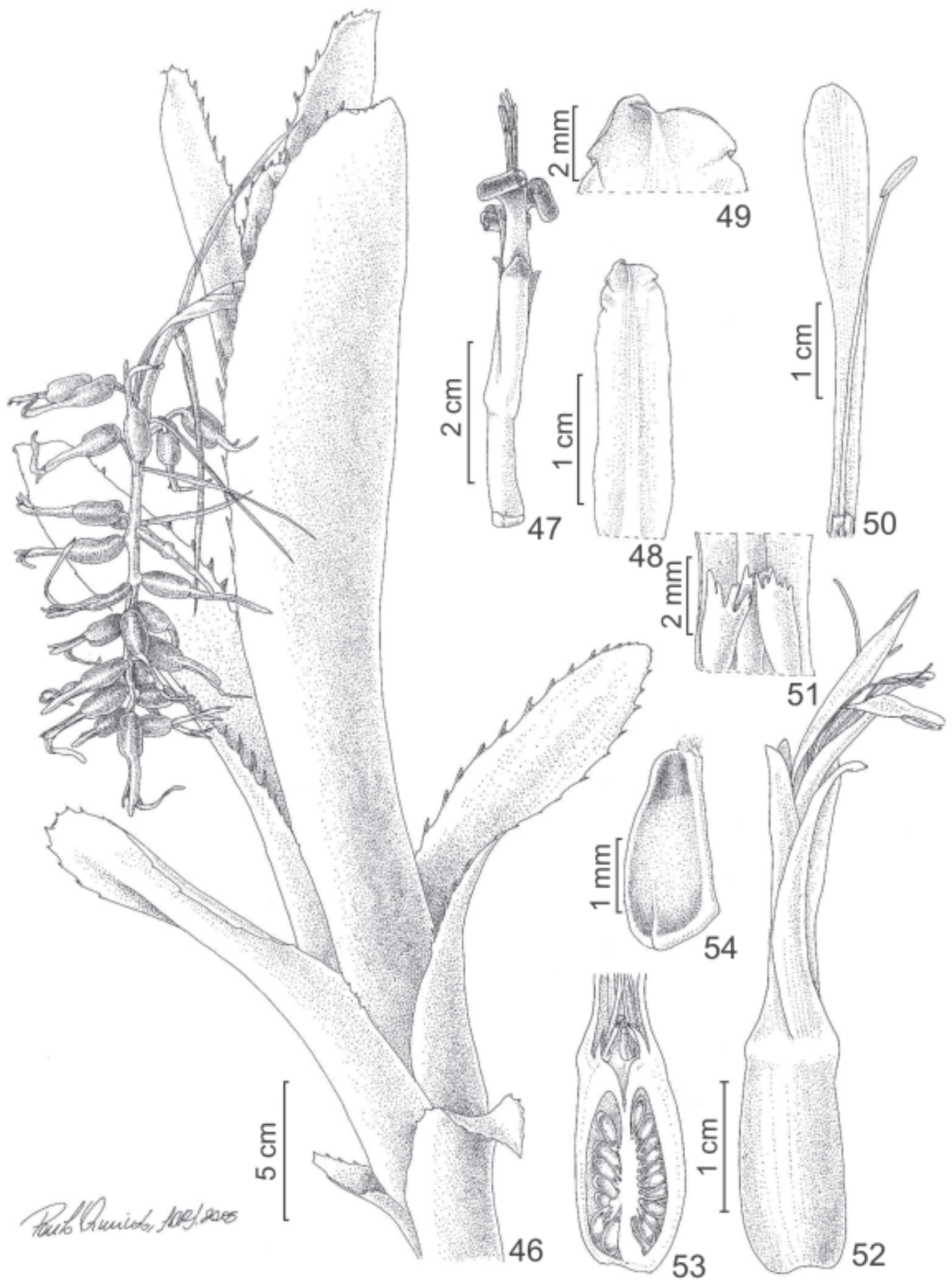

Figuras 46-54. Billbergia vittata Brongn. ex C. Morel. 46. Hábito. 47. Flor. 48. Sépala. 49. Detalhe ápice da sépala. 50. Pétala e estame. 51. Detalhe apêndices petalíneos. 52. Fruto. 53. Fruto em secção longitudinal. 54. Semente (Barros 77). 
50 (R). Itatiaia, Parque Nacional do Itatiaia, Maromba para Macieiras, 17/VIII/1969, fl., Sucre 5812 (RB); id., s/d, fl., Canela 49 (R); id., trilha Hotel Simon, 20/VIII/2005, fl./fr., Barros 77 (R). Nova Friburgo, 9/VI/1967, fl., Pereira 10588 (HB); id., 20/VI/1975, fl., Seidel 714 (HB). Petrópolis, Araras, encosta do Pico da Maria Comprida, 20/III/1977, fl., Martinelli 1332 (RB). Resende, Visconde de Mauá, margens do Rio Preto, 5/IX/1965, fl., Strang 665 (GUA).

Distribuição geográfica: a espécie distribui-se nos Estados de Minas Gerais, do Espírito Santo e Rio de Janeiro, na Floresta Pluvial Atlântica montana e altomontana (Smith \& Downs 1979; Fontoura et al. 1991), campos rupestres e matas de galeria do Cerrado, até $2.000 \mathrm{~m}$ de altitude (Versieux \& Wendt 2006). No Rio de Janeiro a sua ocorrência é restrita à Floresta Pluvial Atlântica montana e alto-montana, ocorrendo a partir dos $800 \mathrm{~m}$ de altitude.

A espécie se caracteriza pela margem das folhas com acúleos evidentes, pelo escapo e raque glabrescentes, pela inflorescência laxa, geralmente espiga dupla, pelo padrão de cores e, sobretudo, pelo ápice da sépala mucronado e recurvado. O epíteto específico é justificado pela presença de listras transversais alvas nas folhas, característica esta que não é compartilhada por todos os espécimes examinados. No Estado do Rio de Janeiro, os espécimes observados in vivo apresentam folhas concolores, sem nenhum vestígio de listras transversais. Os espécimes provenientes de Minas Gerais, especificamente da região de campos rupestres, apresentam folhas claramente vitatas, e alguns espécimes dentre estes apresentam margem foliar lisa. No entanto, este grupo não difere dos espécimes do Rio de Janeiro na morfologia da inflorescência. Mez (1896) mencionou em nota a variação observada de um espécime coletado por Glaziou, de procedência ignorada, com folhas não vitatas e margem foliar sem acúleos.

13. Billbergia zebrina (Herb.) Lindl., Bot. Reg. 13: sub pl. 1068.1827.

=Billbergia cylindrostachya Mez, in Mart., Fl. bras. 3

(3): 395. 1892. Tipo: Rio de Janeiro, Rio de Janeiro,

São Cristóvão, s/d, Glaziou 16427 (holótipo B!) syn. nov.

Planta florida 50-80 cm alt., epífita, roseta tubular. Folhas 5-6, eretas, coriáceas; bainha $19 \times 6-8,5 \mathrm{~cm}$, elíptica; lâmina 30-37×4-6,5 cm, linear a lanceolada, verde, face abaxial com faixas transversais alvo-lepidotas, ápice obtuso-arredondado, margem com acúleos 1,5-2 mm, escapo pendente, $50-57 \mathrm{~cm}, 4-5 \mathrm{~mm}$ diâm., alvo-lanuginoso, entrenós superiores $0,8-1 \mathrm{~cm}$. brácteas do escapo, $13 \times 2,7-3 \mathrm{~cm}$, largo-elípticas, flácidas, róseas, com colorido persistente, base envolvendo parcialmente o escapo, suberetas a patentes, deixando o escapo evidente; as superiores cobrindo $1 / 3$ a $1 / 4$ da inflorescência, ápice agudo. Inflorescência em espiga, densa, 22-40 flores, $13-35 \mathrm{~cm}$, raque não geniculada, alvo lanuginosa, entrenós inferiores 1-3 mm, entrenós superiores 1-2 $\mathrm{mm}$. Brácteas florais inferiores e superiores ca. 0,6 $\mathrm{mm}$ ou ausentes, completamente cobertas pelo indumento, deltóides, ápice agudo, apiculado. Flores suberetas, 5,8-8,2 cm, sésseis, actinomorfas. Sépalas 5-5,5×4,5-5 mm, simétricas, deltóides a ovadas, pardas, alvo lanuginosas, ápice obtuso-arredondado, minutamente apiculado. Pétalas 6,5 $\times 0,3-0,6 \mathrm{~cm}$, lineares a oblanceoladas, verdes, glabras, revolutas, ápice agudo; apêndices 1,9-2,2 cm, semi-cupuliformes; calosidades ausentes. Estames isodínamos, exsertos por 4,5-5,5 cm, verdes ou azuis; filetes crassos, com diâmetro maior que das anteras; anteras ca. 1,8 cm, basifixas. Ovário ca. 1,5 cm, 7-9 mm diâm., turbinado, fortemente sulcado, alvo-lanuginoso, tubo epigíneo ca. $2,5 \mathrm{~mm}$; placentação mediana a mediano superior, ca. $3 \mathrm{~mm}$; óvulos ortótropos apiculados; estigma verde ou azul. Frutos bagas rígidas, ca. $1,4 \mathrm{~cm}, 7 \mathrm{~mm}$ diâm., sulcos persistentes.

Material selecionado: BRASIL. Rio de Janeiro: Angra dos Reis, Ilha Grande, Vila Dois Rios, 23/III/2000, fl., Pinheiro et al. 394 (HB). Armação de Búzios, 14/VIII/1986, fl., Costa et al. 8 (RB); id., Restinga de Manguinhos, 28/III/2000, fr., Fernandes et al. 502 (RB). Cabo Frio, estação de rádio da Marinha, 14/I/1988, fl., Araújo 8440 (GUA). Mangaratiba, divisa com Rio Claro, 17/III/1978, fr., Martinelli 4079 (RB). Maricá, Itaipuaçu, Pedra de Itacoatiara, 17/VII/2001, fl., Silva 754 (HB). Nova Iguaçú, Serra do Marapicú, 24/VI/1988, fr., Giordiano 425 et al. (RB). Parati, Paratimirim, 14/VII/1987, fr., Fontoura 163 (RB). Petrópolis, 26/VI/1988, fl., Martinelli 12975 et al. (RB). Piraí, Ribeirão das Lages, Fazenda Porto do Ozório, 15/VIII/1961, fr., Castellanos 23163 (R). Rio de Janeiro, Tijuca, Excelsior, 1/V/1939, fl., Lutz 1446 (R); id., Grumari, 14/VIII/1968, fl., Sucre 3.528 (RB); id., estrada da Vista Chinesa, 18/V/1994, fl., Oliveira 895 (GUA).

Distribuição geográfica: a espécie ocorre nos Estados da Bahia, Minas Gerais, Rio de Janeiro, São Paulo, Paraná, Santa Catarina e Rio Grande do Sul, na Floresta Pluvial Atlântica e nas matas de restinga, no Cerrado e campos rupestres, até $1.100 \mathrm{~m}$ de altitude. Sua distribuição se interioriza ao sul do país até o Paraguai e a Argentina (Smith \& Downs 1979; Fontoura et al. 1991; Moura et al. 2007; Versieux \& Wendt 2006). No Rio de Janeiro ocorre nas matas de restinga e em florestas baixomontanas e montanas, do nível do mar até cerca de $800 \mathrm{~m}$ de altitude. 
A espécie é a única representante do subgênero Helicoidea no Estado. O tipo de indumento que cobre o escapo, a raque, o ovário e as sépalas, a postura das pétalas na antese e as anteras filiformes longas e basifixas são características comuns a todas as espécies pertencentes ao subgênero. Há, no entanto, uma imprecisão na identificação da espécie em condições onde há sobreposição com outros representantes do subgênero. Billbergia zebrina é distinta das demais pela inflorescência densamente alvo-lanuginosa e, principalmente, pelo ovário turbinado. Mez (1892), ao descrever B. cylindrostachya, considerou a espécie distinta pelas pétalas violáceas e pelo ovário "obovado-estipiforme, muito anguloso". Sua procedência é indicada para o horto de São Cristóvão, se tratando, portanto, de um material de origem incerta. Quanto à forma do ovário, Mez parece não ter interpretado coerentemente a espécie $B$. zebrina e descreve $B$. cylindrostachya utilizando o mesmo caráter, descrevendo-o como é conhecido para B. zebrina.

Embora a forma da antera, o comprimento e a inserção nos filetes sejam caracteres do subgênero Helicodea examinados in vivo, a descrição deste caráter não foi bem explorada nos tratamentos anteriores (Baker 1889; Mez 1896; 1935; Smith \& Downs 1979). Mez (1896; 1935) limitou a sua descrição ao comprimento das anteras e em alguns casos, descreve a sua forma, não mencionando, porém, a inserção nos filetes. Smith \& Downs (1979), nas descrições das espécies de Helicodea, só descreveram detalhadamente as anteras de $B$. zebrina, indicando para esta as anteras com diâmetro mais reduzido que os filetes sem mencionar, no entanto, a inserção destas no filete. As ilustrações da Flora Neotropica (Smith \& Downs 1979) sugerem que a inserção basifixa seja um padrão comum para as espécies pertencentes ao subgênero Helicodea. Este caráter, no entanto, raramente é preservado no material herborizado, dificultando a análise de seu padrão entre as espécies.

Uma boa ilustração da espécie é fornecida por Smith \& Downs (1979).

\section{Billbergia $\mathrm{sp}$.}

Planta florida $35 \mathrm{~cm}$ alt., terrestre, roseta utricular a tubular. Folhas 8-9, suberetas, cartáceas a subcoriáceas; bainha de 10-14×4,5-6 cm; lâmina 30-44×4 cm, linear-lanceolada a lanceolada, verde ou vinácea, face abaxial com faixas transversais alvo lepidotas ou não, ápice agudo-atenuado a obtuso-arredondado, cuspidado quando jovem, margem com acúleos 1-2 mm, nigrescentes. escapo ereto a subereto, $26-36 \mathrm{~cm}, 2-5 \mathrm{~mm}$ diâm., rosa pálido, glabro a glabrescente, entrenós superiores $0,4-2 \mathrm{~cm}$, brácteas do escapo 8,5-11x 1,8-2,3 cm, elípticas, flácidas, vermelhas, com colorido persistente, base envolvendo parcialmente o escapo, suberetas a patentes, ápice agudo. Inflorescência em espiga, laxa, 8-10 flores, ca. $10 \times 9 \mathrm{~cm}$, raque não geniculada, glabra a glabrescente, rósea, entrenós inferiores 0,2-1,5 cm, entrenós superiores 5-7 mm. Brácteas florais inferiores semelhantes as do escapo, ca. $7,5 \times 2 \mathrm{~cm}$, as superiores ausentes ou até ca. $5 \times 2 \mathrm{~mm}$, estreito ovadas a deltóides, róseas. Flores suberetas ou secundas, 6,5-7 cm, inferiores curto-pediceladas e superiores sésseis, pedicelo 1-2 mm, zigomorfas. Sépalas 2,6-3×0,6 cm, simétricas, oblongas a oblongo-obovadas, róseas com 1/6 apical roxo, glabrescentes, ápice agudo ou obtuso arredondado, com ou sem pequeno apículo. Pétalas 4,7-5×0,7 cm, espatuladas, verdes com $1 / 4$ a $1 / 3$ apical roxo, recurvadas, ápice obtuso arredondado. Estames isodínamos; filetes antipétalos adnatos às pétalas por ca. $5 \mathrm{~mm}$; anteras ca. $5 \mathrm{~mm}$, dorsifixas. Ovário 1,4-2 cm, 5-6 mm diâm., subcilíndrico, liso, verde, glabrescentes; tubo epigíneo 3-5 mm; estigma verde ou azul. Frutos não observados.

Material examinado: BRASIL. Rio de Janeiro: Arraial do Cabo, Ilha de Cabo Frio, 10/XI/2004, fl., Barros 60 (R). Macaé, ARIE Itapebussus, Balneário das Garças, 5/XII/2004, fl., Barros 63 (R).

Distribuição geográfica: o táxon é considerado, até o momento, endêmico do sub-bosque de restinga da Região dos Lagos.

É afim a B. amoena e a B. lymanii. O escapo, a raque, o ovário e as sépalas glabrescentes, o escapo crasso e ereto, as brácteas do escapo com colorido persistente e a inflorescência laxa e pauciflora são características que aproximam o táxon das duas espécies. As brácteas do escapo elípticas e as sépalas simétricas e longas o aproximam da primeira. O ovário liso, as flores inferiores pediceladas e as sépalas róseas concolores são características que o aproximam da segunda. Embora B. lymanii esteja descrita como pedicelada, com pedicelos com ca. $5 \mathrm{~mm}$, o táxon referido apresenta um pedicelo de no máximo ca. $2 \mathrm{~mm}$ e as flores foram consideradas curto-pediceladas a sésseis. A espécie B. lymanii, ainda possui sépala assimétrica e ovário vermelho.

Os dois espécimes examinados são distintos no aspecto vegetativo. O espécime Barros 60 possui roseta mais robusta com folhas subcoriáceas, freqüentemente vináceas na face abaxial. O espécime Barros 63 apresenta porte menor com folhas cartáceas, verdes na face abaxial. Quanto ao aspecto reprodutivo, os dois espécimes são semelhantes, e por isso foram considerados circunscritos no mesmo táxon.

Táxons pouco conhecidos

Billbergia lietzei E. Morren, Belg. Hort. 31: 97, pls 5-7. 1881. 
A espécie $B$. lietzei só é conhecida pela coleta do material tipo, um espécime da coleção viva de Lietze, cuja procedência é incerta. $\mathrm{O}$ material tipo e a descrição original foram examinados em fotocópia e ambos indicam afinidade com $B$. iridifolia. O confronto de características das duas espécies foi feito pelo próprio autor da espécie (Morren 1881) e em tratamentos posteriores (Mez 1892; Smith \& Downs 1979) O táxon foi considerado duvidoso pela ausência de registro de coleta posterior ao tipo, pela incerteza quanto à sua procedência e pela similaridade morfológica com a espécie $B$. iridifolia, o que, no entanto, exigiria o exame do material vivo para sugerí-lo como uma sinonímia.

Billbergia seidelii L.B. Sm. \& Reitz, Phytologia 10: 485, pls. 2, figs 6, 7. 1964.

A espécie é conhecida somente pelo material tipo, uma coleta de Seidel, com a procedência indicada para a estrada de Niterói para Campos, atualmente conhecida como BR-101. A recoleta a partir desta indicação é inviável e o conhecimento da espécie viva depende do acaso uma vez que a procedência indicada no protólogo é vaga e envolve uma área muito extensa.

Táxon de ocorrência duvidosa para o Estado do Rio de Janeiro

Billbergia morelii Brongn., Portef. Hort. 2: 97, pl. 1848.

A espécie apresenta grande afinidade com B. euphemiae, que é uma espécie polimórfica. Morren (1872), Baker (1889), Mez (1892) e Smith \& Downs (1979) destacaram a orientação da raque, a disposição das flores ao longo da raque, a coloração das brácteas, o comprimento das brácteas florais inferiores e presença ou ausência de pedicelo como características dignósticas na separação das duas espécies. Os caracteres que se referem à orientação da raque e à disposição das flores ao longo da mesma foram também utilizados por Smith (1955) para descrever a variedade B. euphemiae var. nudiflora. Este segundo caráter, no entanto, se mostrou muito variável entre os espécimes examinados. Quanto à distinção da coloração das brácteas - vermelhas em $B$. morelii e róseas em $B$. euphemiae - é notória a dificuldade dos coletores na informação das cores dessas estruturas.

Os materiais identificados como B. morelii ocorrentes no Estado do Rio de Janeiro (Moutinho \& Ventura 35 HB, Santos Lima 15710 RB e Fontoura 10 $\mathrm{RB}$ ) estão mal preservados ou apresentam características insuficientes para uma descrição da espécie. Portanto, as informações contidas nas etiquetas e a avaliação do próprio material herborizado não garantem uma identificação precisa, sendo necessário para tal uma reavaliação da circunscrição de ambas as espécies a partir de trabalhos de campo.

\section{Agradecimentos}

Ao Conselho Nacional de Desenvolvimento Científico e Tecnológico-CNpq, pela bolsa de mestrado concedida à primeira autora; à Dra. Tânia Wendt, Dra. Rafaela Forzza, ao Dr. Gustavo Martinelli e a dois revisores anônimos, pelas críticas e sugestões; ao ilustrador Paulo Ormindo, aos curadores dos herbários citados no texto, e ao Programa de Pós-graduação em Ciências Biológicas (Botânica)-UFRJ e à Coordenação de Aperfeiçoamento de Pessoal de Nível Superior-Capes, pelo auxílio financeiro através do PROAP.

\section{Referências bibliográficas}

Baker, J.G. 1889. Handbook of the Bromeliaceae. London, George Bell \& Sons.

Fontoura, T.; Costa, A. \& Wendt, T. 1991. Preliminary checklist of Bromeliaceae of Rio de Janeiro State, Brazil. Selbyana 12: 1-45.

Fontoura, T. 1994. New synonymies in the genus Billbergia Thunb. (Bromeliaceae). Selbyana 15: 79-81.

Holmgren, P.K. \& Holmgren, N.H. 1998 [continuously updated]. Index Herbariorum: A global directory of public herbaria and associated staff. New York Botanical Garden's Virtual Herbarium. http://sweetgum.nybg.org/ih/

Luther, H.E. 2006. An alphabetic list of Bromeliad Binomials. The Marie Selby Botanical Gardens. $10^{\text {th }}$ ed. Florida, Bromeliad Society International, Sarasota.

Mez, C. 1892. Bromeliaceae. In: C.F.P. von Martius; A.W. Eichler \& I. Urban (eds.). Flora Brasiliensis 3: 173-674. München, Leipzig.

Mez, C. 1896. Bromeliaceae. In: A.L.P.P. de Candolle \& A.C.P. de Candolle. Monographiae phanerogamarum 9: 1-990. Paris, G. Masson.

Mez, C. 1934-5. Bromeliaceae. In: H.G.A. Engler. Das Pflanzenreich. Berlin (Wilhem Engelmen), IV. 32 (Heft 100, 1-4), 667 p., il.

Morren, C.J.E. 1872. Notice sur le Billbergia euphemiae. Belgique Horticole 22: 11, pl 1-2.

Morren, C.J.E. 1881. Description du Billbergia lietzei sp. nov. Belgique Horticole 31: 97, pl. V-VII.

Moura, R.L.; Costa, A.F. \& Araujo, D.S.D. 2007. Bromeliaceae das Restingas Fluminenses: Florística e Fitogeografia. Arquivos do Museu Nacional 65: 139-168.

Pereira, E. 1975. Species Novae in Brasilia Bromeliacearum - VIII. Sellowia 27: 76-91.

Radford, A.E. 1986. Fundamentals of Plant Systematics. New York, Harper \& Row, Publ. Inc.

Reitz, R. 1983. Bromeliáceas e a Malária-Bromélia endêmica. In: Flora Ilustrada Catarinense, Itajaí, Fasc. BROM. 559p., 118 est., 106 mapas.

Smith, L.B. 1955. The Bromeliaceae of Brazil. Smithsonian Miscellaneous Collections 126: 1-290.

Smith, L.B. \& Downs, R.J. 1979. Bromeliaceae, subfamily Bromelioideae. Flora Neotropica, monograph 14, part 3: 1493-2142, fig. 468-730.

Versierux, L.M. \& Wendt, T. 2006. Checklist of Bromeliaceae of Minas Gerais, Brazil, with notes on taxonomy and endemism. Selbyana 27: 107-146.

Weberling, F. 1989. Morphology of flowers and inflorescences. Cambridge, Cambridge University Press. 